\title{
Understanding the decline and resilience loss of a long-lived social- ecological system: insights from system dynamics
}

\author{
Alicia Tenza $^{1,2}$ Irene Pérez $^{3}, \underline{\text { Julia Martínez-Fernández }}^{4}$ and Andrés Giménez $^{1}$
}

\begin{abstract}
Collapse of social-ecological systems (SESs) is a common process in human history. Depletion of natural resources, scarcity of human capital, or both, is/are common pathways toward collapse. We use the system dynamics approach to better understand specific problems of small-scale, long-lived SESs. We present a qualitative (or conceptual) model using the conceptualization process of the system dynamics approach to study the dynamics of an oasis in Mexico that has witnessed a dramatic transition to decline in recent decades. We used indepth interviews, participant observation, expert opinions, and official statistical data sets to define the boundaries, and structure in a causal loop diagram of our studied system. We described historical trends and showed the reference mode for the main system variables (observed data), and analyzed the expected system behavior according to the system structure. We identified the main drivers that changed the system structure, as well as structural changes, and the effects of these changes on the dynamics, resilience, and vulnerability of this SES. We found that the tendency of this SES toward collapse was triggered by exogenous factors (growth of modern agriculture in nearby valleys, and socio-political relocation), and was maintained by an endogenous structure. These structural changes weakened the resilience of this SES. One of these changes resulted in a long-term maladaptation of the SES, which increased its vulnerability to frequent system disturbances (hurricanes and droughts). The conceptual model developed provides an in-depth qualitative description of the system, with an important amount of qualitative and quantitative information, to establish the structural hypothesis of the observed behavior. Using this qualitative model, the next research steps are to develop a quantitative model to test the qualitative theories, and to explore future scenarios of system resilience for decision-making processes to improve local conditions and restore the well-functioning of the system.
\end{abstract}

Key Words: collapse; depopulation process; feedbacks; maladaptation; oasis of Comondú; qualitative model; system structure

\section{INTRODUCTION}

Civilizations, societies, and cultures have lived boom-bust cycles throughout human history (Turchin and Nefedov 2009). Depletion of natural resources, scarcity of human capital, or both, is/are common pathways toward collapse (Motesharrei et al. 2014). This is consistent with insights into complex adaptive systems and the resilience paradigm by means of adaptive cycles (Holling 1987, 2001, Abel et al. 2006, Walker et al. 2006), where the collapse of social-ecological systems (SESs) is usually preceded by loss of (social, human, natural, physical, and/or financial) capital, and loss of resilience. According to historical social changes, the best-known drivers that can lead to the collapse of SESs are population growth, technological change, resource degradation, catastrophes, trade, war, and competition both within and between societies (Cocks 2003). Be it generalized, the ecological strain (use of natural resources) and economic stratification (wealth distributed in society) are indicated as the common factors that can lead to complete collapse (Motesharrei et al. 2014). Some of these drivers might belong to the system itself (as endogenous factors), such as demographics changes, wealth distribution, or use of natural resources. However, others remain outside the system (as exogenous factors) and are related to changes on higher scales that affect internal dynamics (e.g., socioeconomic changes, natural disasters, technological change). A better understanding of the relationships between changes on higher scales with changes in the structure and dynamics of SESs is needed to better address their specific problems, and to comprehend their changes on adaptability, resilience, and vulnerability (Young et al. 2006).
While some general theoretical models have been successfully developed to understand SESs dynamics that lead to collapse (Brander and Taylor 1998, Anderies 2000, Motesharrei et al. 2014), addressing the case-specific study of SESs has received less attention. Most of these case studies rely on the adaptive cycles theory (Baral et al. 2010, Urgenson et al. 2010, Vang Rasmussen and Reenberg 2012). Although this approach is useful for recognizing changes in system behavior, an adaptive cycle is not predictive, and theoretical phases are not necessarily sequential and cannot explain causes and effects in particular cases because they are relatively abstract (Abel et al. 2006). The system dynamics approach can be a useful methodological alternative because it focuses on the structural causes of the problematic behavior of the systems, deepening into causal and feedback relationships (Roberts et al. 1983, Vennix 1996, Sterman 2000, Jørgensen and Bendoricchio 2001). Knowing the structural causes of specific problems could efficiently support decision-making processes about management alternatives that promote the wellfunctioning and conservation of SESs (Costanza and Ruth 1998), especially if we wish to move away from panaceas that frequently fail (Ostrom et al. 2007).

The system dynamics approach has been widely used in the study of SESs, and has focused on different topics, such as sustainability (Saysel et al. 2002, Lacitignola et al. 2007, Tomlinson et al. 2011, Li et al. 2012, Martínez-Fernández et al. 2013, Vidal-Legaz et al. 2013, Banos-González et al. 2015, 2016), water management (Xiao-Qing et al. 2012, Sanga and Mungatana 2016), changes in land use (Dale et al. 1993, Duffy et al. 2001, Evans et al. 2001, Portela and Rademacher 2001, Marín et al. 2012, Baur and Rinder

${ }^{1}$ Departamento de Biología Aplicada, Ecología, Universidad Miguel Hernández, Elche, Spain, ${ }^{2}$ Centro de Investigaciones Biológicas del Noroeste, La Paz, Mexico, ${ }^{3}$ School of Social Work, Columbia University, New York, USA, ${ }^{4}$ Fundación Nueva Cultura del Agua, Zaragoza, Spain 
2015), and effects of resource management and social practices on wildlife (Musacchio and Grant 2002, Bueno and Basurto 2009, Pérez et al. 2012). However, currently there are no studies focused on the causes of decline of small-scale, long-lived SESs.

Many of these small-scale, long-lived SESs are local communities that rely on family farming. Family farms manage about $70-80 \%$ of the world's agricultural land, and produce more than $80 \%$ of the world's food (FAO 2014). Therefore, these systems play a key role not only in the sustainable use of natural resources but also in food security. Preserving long-lived SESs helps maintain institutional diversity, which implies a rich set of solutions of social systems by adapting to the ecological and socioeconomic context. This is a critical point if we consider that a collection of many small-scale SESs may better address environmental problems on a global scale than a smaller number of larger scale nation states (Janssen et al. 2007).

We use the system dynamics approach to study the structural causes responsible for the dramatic transition from wellfunctioning to decline of a small-scale, long-lived SES - the oasis of Comondú in Baja California Sur (BCS), Mexico. The oasis of Comondú is one of the largest oases of BCS. We present the conceptual model of this SES. This initial step of system dynamic modeling is an iterative process, which requires the most time and effort. By itself, it is a useful and qualitative branch of system dynamics (Wolstenholme 1990, Coyle 2000). However, and more importantly, it is considered a necessary step to quantitative modeling because it allows visualization of the modeler's concepts and the system hypothesized structure related to the observed behavior (Jørgensen and Bendoricchio 2001).

We used in-depth interviews, participant observation, expert opinions, and official statistical data sets to build a conceptual model to better understand the causes and effects and the endogenous or exogenous factors that have dangerously modified the system structure and behavior. For this purpose, we qualitatively analyzed the structure (variables, relationships, and feedbacks) of this SES. We located the transition point from wellfunctioning to decline in time. We also identified the main drivers of this behavioral change in relation to structural changes (are these drivers endogenous, exogenous, or both?). Finally, we explored system changes and their impact on the system's resilience and vulnerability. As far as possible, we included quantitative data derived from statistical data sets and in-depth interviews in order to quantitatively characterize the system (parameters and data needed for quantitative modeling, and observed data needed in future model evaluation). We found that exogenous drivers triggered the decline of our studied SES, but the endogenous structure has also maintained the system in this undesirable state. The resilience has been reduced and the structural changes have made the SES more vulnerable to historical frequent disturbances (e.g., hurricanes). The conceptualization process of the system dynamics approach has provided a profound qualitative understanding of the system structure and the main causes that pulled the system dynamics toward decline. It has allowed us to collect qualitative and quantitative data needed in future modeling steps. In addition, it has contributed to building a strong confidence relationship with local actors, which could support possible future participatory processes. This is a first step to formalizing a quantitative computational model that could support decision-making processes for improving local conditions and restoring the system's well-functioning.

\section{METHODS}

\section{The study area: the oasis of Comondú}

In Baja California Sur, Mexico, under pronounced isolation and aridity conditions, oases are the most important long-lived, smallscale SESs, especially when we consider the biodiversity, history, and culture of this region (Arriaga and Rodríguez-Estrella 1997, Cariño et al. 2013, Cariño and Ortega 2014). After the Jesuits arrived in the late 17 th century, natural wetlands were transformed into cultural landscapes, similar to those in northern Morocco and Spain. The indigenous culture and the western Mediterranean culture joined to form a society that was characterized by austerity, self-sufficiency, and the comprehensive use of biological diversity (Cariño 2001). In all the oases of BCS, traditional irrigated agriculture was successfully practiced, and was supplemented by fishing in coastal zones and by livestock in mountain regions.

The oasis of Comondú is one of the largest and best ecologically preserved oases of BCS. It has been a RAMSAR site since 2008, and is currently in the process of forming part of the Sierra de La Giganta y Guadalupe Biosphere Reserve. It is located $130 \mathrm{~km}$ from Ciudad Constitución, the municipality seat (Fig. 1), in the Sierra de La Giganta mountain range, and is poorly connected to other nearby villages or towns, like Loreto. The area under study comprises 107,000 ha (Fig. 2), which includes 80 ha of irrigated land, 70,000 ha of communal land, and 37,000 ha of private land in the immediate surroundings; the last two large areas are devoted to ranching. Most inhabitants live in the communities of San José de Comondú and San Miguel de Comondú, both located in a canyon that is $16 \mathrm{~km}$ long and 50$500 \mathrm{~m}$ wide, where the irrigated land is also located (Fig. 2). The remaining inhabitants live on ranches with homes sited around temporary ponds and streams in the immediate surroundings.

Fig. 1. Location of the oasis of Comondú.

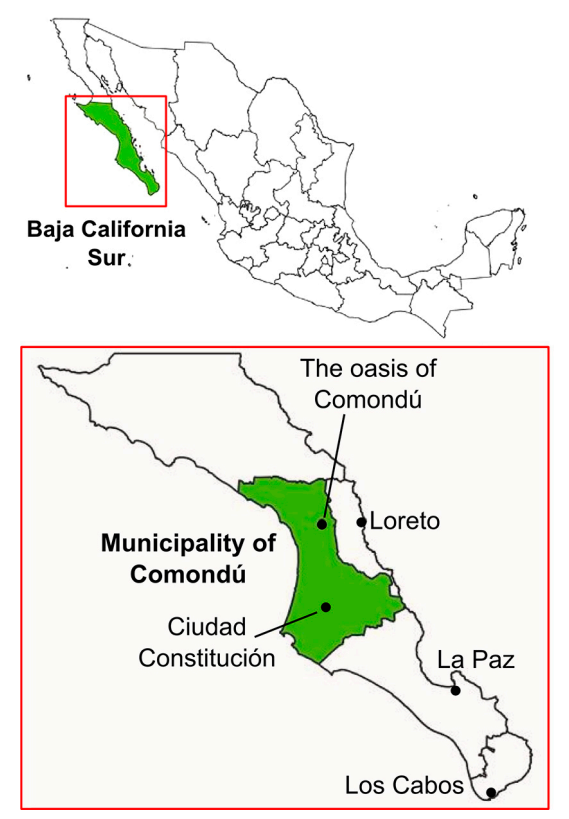


Fig. 2. The study area with details of the irrigated land and local communities.

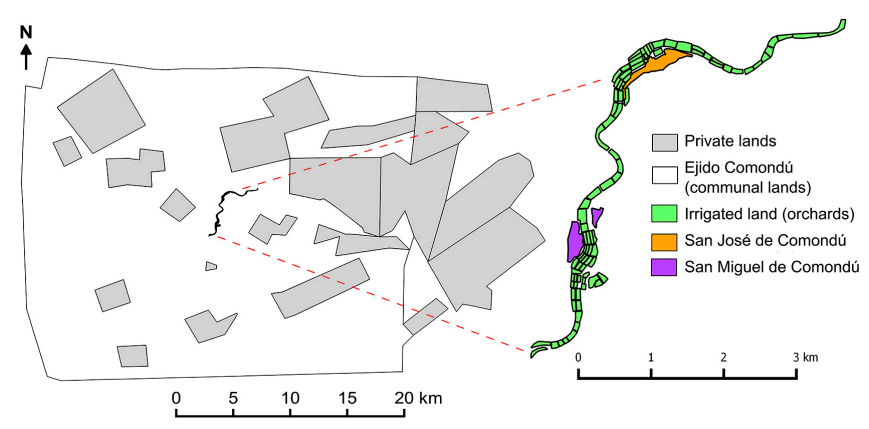

The area belongs to the Sonoran Desert. Rainfall is distributed during two main periods. One period coincides with the hurricane season in the Pacific (from mid-May to the end of November) and involves $70 \%$ of the annual rainfall. The other period, commonly known as "equipatas," takes place between November and January, and represents $21 \%$ of the annual rainfall. Extreme weather events like hurricanes and droughts are frequent in this region. Average annual rainfall is $175 \mathrm{~mm}$, and temperature oscillates between $10^{\circ}$ and $36^{\circ} \mathrm{C}$, with an average of $23^{\circ} \mathrm{C}$ (Tenza et al. 2013).

\section{The system dynamics approach, qualitative data, and qualitative models}

System dynamics allowed us to analyze world problems from a comprehensive point of view by focusing on the structure and dynamics of complex systems. The source of this complexity was nonlinear relationships between system components, feedback, and material or information delays. Jay W. Forrester developed system dynamics in the 1950s, and he applied this methodology to industrial problems (Forrester 1958, 1961). His success in analyzing industrial business cycles extended the use of system dynamics to other fields, like urban problems (Forrester 1969) and global problems (Meadows et al. 1972, 1974, Forrester 1973). System dynamic modeling has proved particularly useful for studying complex systems like SESs (Roberts et al. 1983, Costanza and Ruth 1998, Martínez-Fernández et al. 2000, Pérez et al. 2012, Banos-Gonzalez et al. 2015, Turner et al. 2016).

Building management models is one of the applications of the system dynamics approach (Vennix 1996). It assesses alternative management options and supports decision-making processes to solve specific problems, and stems from a profound understanding of the system structure. Building a management model is an iterative and a continuous learning process about the system, which could be divided into three main phases: (1) conceptualization and qualitative modeling, (2) quantitative modeling, and (3) exploring future scenarios. Despite the mathematical character associated with the procedure, it is also recognized that most information available to the modeler is qualitative (Forrester 1992, Luna-Reyes and Andersen 2003). As suggested by Forrester (1992), the available information declines (in many orders of magnitude) from mental to written information, and again from written to numerical information.
Although it could have a role in quantitative modeling, model evaluation, or exploration of alternative management options, the greatest amount of qualitative information is used in the conceptualization stage (Forrester and Senge 1980, Randers 1980, Richardson and Pugh 1981, Wolstenholme 1990, Coyle 2000, Sterman 2000, Luna-Reyes and Andersen 2003). We focus on this first stage, which is critical, because it provides a profound qualitative understanding of the system's functioning (Vennix 1996, Downing et al. 2014), allows us to visualize the system's hypothesized structure, and establishes the basis for the construction of the quantitative dynamic simulation model (Jørgensen and Bendoricchio 2001).

Qualitative models are the result of conceptualizing the problem under study. We specified "problem" rather than system because it helps delimit the study in time and space, and helps determine the elements that form part of the model. Delimitation of real systems is difficult given their complexity. Identifying a problematic behavior is a key issue for determining the variables and relationships involved (Vennix 1996). The problematic behavior perceived from empirical knowledge and observed data is the reference mode. The consistency between model behavior and the reference mode is one of the factors that enhances trust in the developed model (Vennix 1996, Solecki and Oliveri 2004, Happe 2005, Bert et al. 2011, Martínez-Fernández et al. 2013).

Qualitative models are often represented by causal loop diagrams, which include the main system variables linked to the problematic behavior, the connections between these variables by means of arrows, and the sign of these interactions (i.e., positive or negative). A relationship is positive when an increase in the value of a variable brings about an increase in the other (i.e., both variables change in the same direction). In contrast, a relationship is negative when an increase in the value of a variable leads to a decrease in the other (i.e., the variables change in opposite directions). Feedback loops are composed of two variables or more that are involved in a closed chain of a cause-and-effect relationship. By multiplying the signs of the relationships involved in feedback, we determine the overall loop sign. Positive feedback loops represent reinforcing processes (either an increase or a decrease), and do not tend to equilibrium. These cycles will continue in the direction of their momentum until an external factor intervenes and breaks the cycle. When they have favorable results (like growth), they are known as "virtuous cycles," but when they have detrimental results (like development trap), they are known as "vicious cycles." In contrast, negative feedback loops represent self-regulatory processes that tend to stabilize dynamics. The variables that affect system dynamics, but are not influenced by it, are external variables or forcing functions (e.g., climatic and socioeconomic factors like rainfall, market prices).

Qualitative models represent the hypothesis about the system structure and behavior (i.e., the response to "What structure is responsible for the observed behavior?"). They allowed us to analyze the system's structural changes. Among these changes, we found (1) a change in the relative weight of the different interactions, (2) a change in the sign or the direction of relationships or loops, and (3) the addition or removal of interactions. 
Fig. 3. The conceptualization process. Numbers indicate the order of the methodological steps. The main information sources are marked in yellow. Dashed lines imply information feedback.

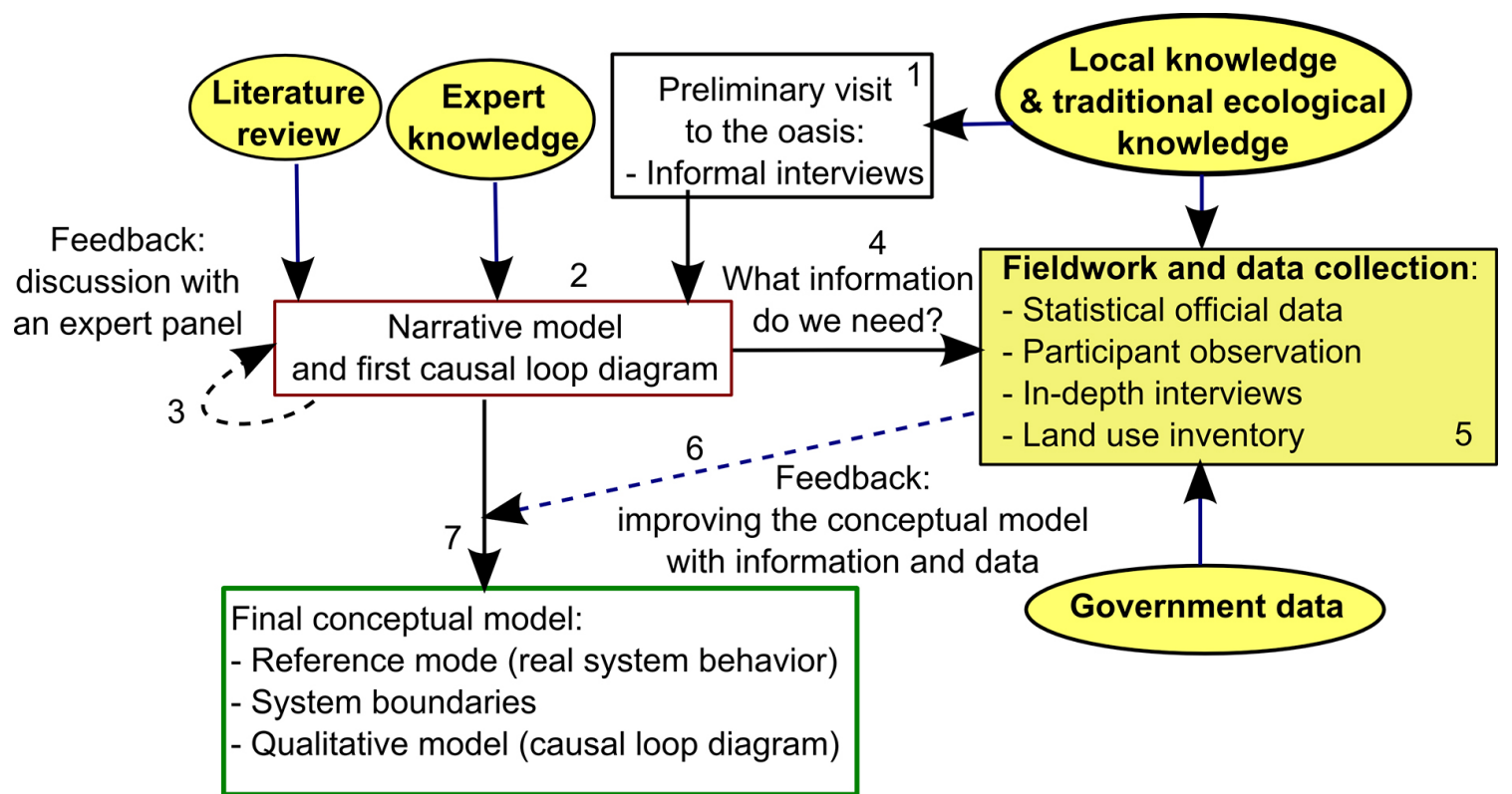

\section{Conceptualization process and reference mode building}

The conceptualization phase was an iterative process with five main sources of information: (i) scientific literature, (ii) expert opinion, (iii) local and traditional ecological knowledge, (iv) government data, and (v) fieldwork. This process is outlined in Fig. 3.

In 2009, we reviewed the available scientific literature about oases of Baja California Sur, but specific information about the oasis of Comondú was scarce. We made a first visit to the oasis in 2009, where we conducted informal interviews with local inhabitants. A workshop was conducted then, where we gathered the expert opinions of scientific researchers from a network called RIDISOS (Appendix 1) (a Spanish acronym that stands for "Interdisciplinary Network for Integral and Sustainable Development of the Oasis of Baja California Sur") to initially define the main problem. After processing the information, in 2010 we built the first conceptual model in a narrative form, which means that we wrote a description of the history of the oasis and the behavior of the main items of the system (social-demographic factors, economic and productive activities, and the main external factors that have affected the system). This narrative model was accompanied by a first extensive causal loop diagram. Corrections, suggestions, and comments were added telematically by RIDISOS members to reach a consensus about the system's problematic behavior, system boundaries, and its elements (variables, relationships, and the signs of relations). Once the main variables were identified, we began fieldwork to improve our knowledge about the system and to obtain historical data series to build the reference mode.

During the 2010-2012 period, we went on four stays that lasted from 15 days to 4 months. Data sets of climate, population, and market prices were obtained from different government agencies in Mexico. However, the small scale of the case study hindered the collection of data about production activities (e.g., farmlands in production, production volumes). To obtain household-type information, we conducted a participant observation during 5 weeks, and 52 in-depth interviews with 43 interviewees (Table 1). The people interviewed were selected by snowball sampling; $24 \%$ were women, and the average age of the interviewees was 49 years. The main topics of the interviews were life conditions over time, problems and characteristics of the rancher system, sale of livestock products with and without intermediaries, problems and characteristics of irrigation systems, and the life story of emigrants who left the oasis in recent decades (Appendix 2). All the interviews were transcribed, and the the interviewees' experiences and impressions obtained through observation were registered in notebook diaries. Both methods-participant observation and interviews - are recognized social research techniques that are especially useful in the conceptualization process (Luna-Reyes and Andersen 2003). The interview is the more widely used method, but if time and resources permit, the participant observation is the most complete form of sociological datum (Becker and Geer 1957). The participant observation is the method in which the observer (the researcher) participates in the daily life of the people under study. This method allows the observer to more deeply understand the relationships between the people under study; to unearth personal motivations, interests, and conflicts; to detect the personal distortions of reality; and to raise awareness and sensitivity about many problems that would be overlooked in interviews. In addition, it reduces the error associated with the interpretation of the words used by interviewees (Becker and Geer 1957).

We made a land use inventory to characterize the dynamics of irrigated land. This allowed us to know the areas with production and the state of orchards. In the same way, we counted and located the number of occupied and abandoned ranches with the support 
of satellite images (Google Earth, DigitalGlobe). The historical data of land use (e.g., year of abandonment, crops, users), and dynamics of occupancy and abandonment of ranches were collected through interviews with key informants.

Table 1. List of in-depth interviews classified by topic. The column $(n)$ indicates the number of interviewees, $(N)$ depicts the number of potential interviewees according to the target population, and $\left(n_{\mathrm{i}} / N_{\mathrm{i}}\right)$ denotes the percentage of the ratio between interviewees and the potential interviewees for each topic.

\begin{tabular}{|c|c|c|c|}
\hline Topic & Target population & $n$ & $\begin{array}{c}\mathrm{n}_{\mathrm{i}} / N_{\mathrm{i}} \\
(\%)\end{array}$ \\
\hline $\begin{array}{l}\text { Life in the communities of the oasis } \\
\text { of Comondú and dynamics of } \\
\text { irrigated land }\end{array}$ & $\begin{array}{l}\text { Landowners in } \\
\text { irrigated lands }\end{array}$ & 24 & 33.8 \\
\hline Livestock activity & Families with ranches & 19 & 39.6 \\
\hline $\begin{array}{l}\text { The role of intermediaries of } \\
\text { livestock products }\end{array}$ & Intermediaries & 2 & 100 \\
\hline $\begin{array}{l}\text { Life story and opinion of the } \\
\text { emigrants of the oasis of Comondú }\end{array}$ & $\begin{array}{l}\text { Emigrants of } \\
\text { Comondú (1940-2000) }\end{array}$ & 7 & $0.38^{\dagger}$ \\
\hline
\end{tabular}

In-depth interviews and participant observation were essential to improve and enrich the initial conceptual model. The qualitative and quantitative information derived from the interviews was used to construct the reference mode (especially for the economic and productive activities-related variables), and to define parameters that will be needed in the next step of quantitative modeling (see a summary of quantitative data in Appendix 3). Official statistical data sets and the land use inventory results were used primarily to build the reference mode of the main model variables. The regional market prices of the main agricultural and livestock products of the oasis were converted from current prices into constant prices to avoid inflation effects. We used Fisher's price index, with 1975 as the base year, for a set of agricultural and livestock products of BCS during the study period. The results presented herein show the final conceptual model after two improvement cycles.

\section{RESULTS}

Due to the cyclicity of the conceptualization process, the methods and results were interrelated. Defining the system boundaries, studying historical data, and building the reference mode and the causal loop diagram therefore formed part of both the methods and results. Improvement in one of these tasks led to changes and improvements being made in other tasks. However, in order to facilitate their presentation, we first defined the system boundaries and presented the SES structure in a causal loop diagram, and analyzed the system's feedback loops to explain expected system behavior according to the system structure. We described historical trends and showed the reference mode for the main system variables (observed data). Finally, we identified the main drivers that changed the system structure,as well as structural changes, and the effects of these changes on the dynamics, resilience, and vulnerability of the SES of the oasis of Comondú.

\section{System boundaries and the underlying social-ecological system structure}

The oasis of Comondú changed dynamics from well-functioning to declining. The population dynamics is the system variable that best reflects this tendency (Fig. 4). To analyze the causes and effects, we selected the piece of reality associated with problematic behavior: the depopulation process (Fig. 5). From 1900 to 1940 , the trend moved toward growth. Yet from that point, the trend moved toward decline. Ideally, the time boundary should begin years before this turning point. Due to data scarcity for these years, our time horizon started in 1940. Spatial boundaries included the area of local communities (San José and San Miguel of Comondú), and the area used for their production activities (agriculture on irrigated lands and livestock on rangelands). We identified the main population dynamics variables, which in this case, strongly relied on the availability of local employment, services, and infrastructure. Likewise, these factors depended on the productive activities and economy of the oasis. Three main forcing functions (or external conditions) affected system dynamics: market prices, rainfall, and hurricanes. The qualitative model showed the relation between system variables and the effects on population dynamics (Fig. 6).

Fig. 4. The oasis of Comondú population (1900-2010). The red dashed line indicates the turning point. Source: population and housing censuses of the Mexican National Institute of Statistics and Geography (INEGI 2011).

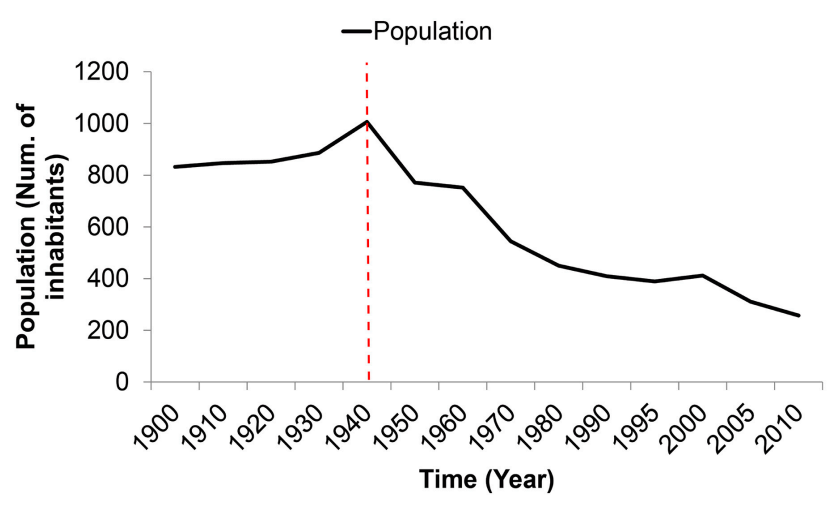

We identified nine feedback loops in the system structure (Table 2), of which seven were positive and two were negative. There was a direct positive feedback loop between population and services and infrastructure in relation to the maintenance of these services with human capital. Services and infrastructure represents public services (education, health, security, transportation, communication) and private services (local shops, professional skills, community works), physical infrastructure (irrigation canals, dams, urban furniture), and social infrastructure (local institutions). Each productive activity (agriculture and livestock) was embedded in a virtuous cycle that led to economic growth. The more irrigated land in production and the more occupied the ranches, the higher the production (agricultural production and livestock production) and profitability (profitability of agriculture and profitability of livestock), which encourages an increase in the amount of irrigated land and the number of ranches. This growth trend was also supported by two additional positive feedback 
Fig. 5. Defining system boundaries and components. The sketch summarizes the main issues to define the system, starting from the observed problem.

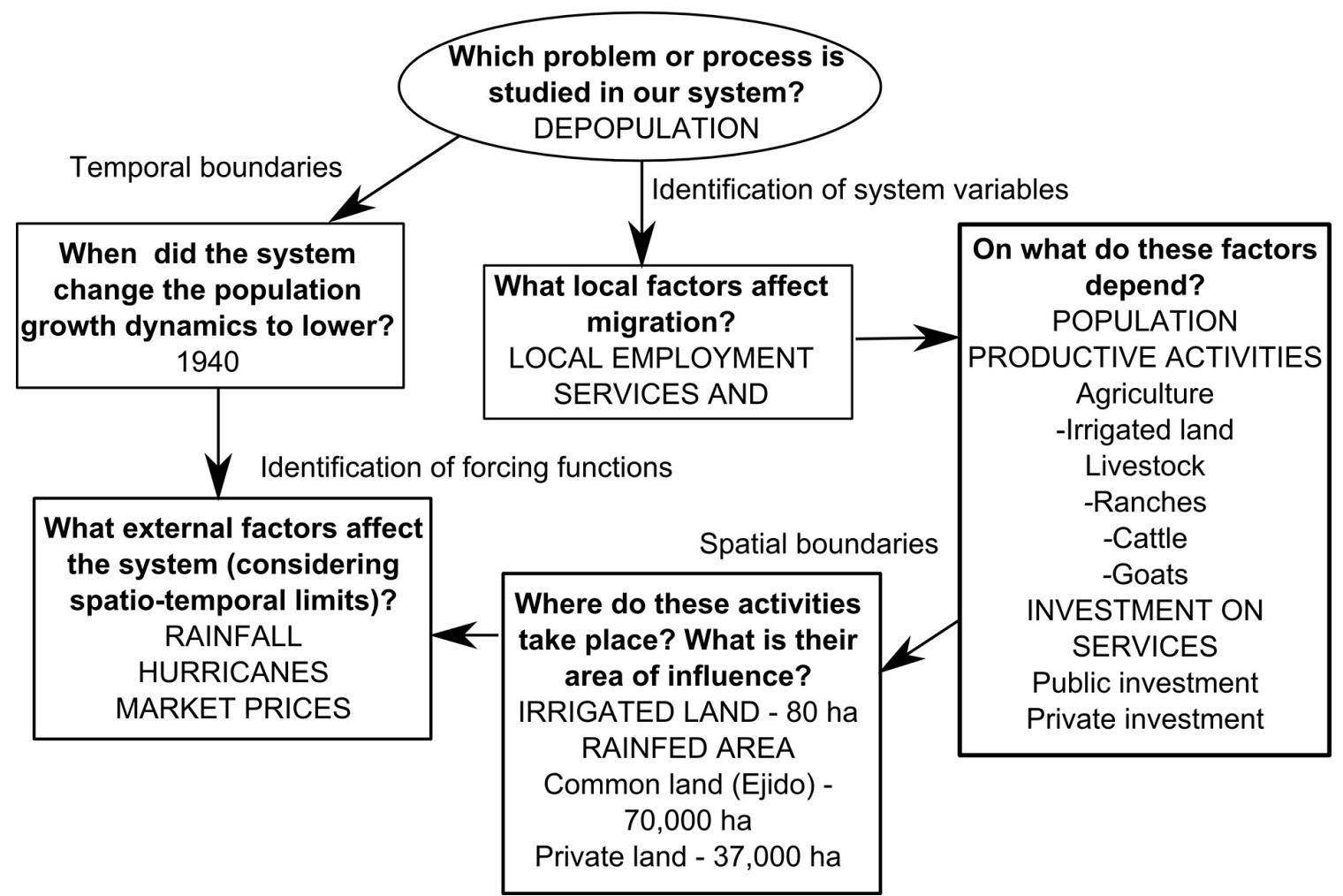

loops per productive activity. One was linked to the local employment offer, and the other to services and infrastructure. As the amount of irrigated land (hectares in production) and the number of ranches increased, the local employment offer also increased, which led to an increase in population. As the population became larger, the need to increase the amount of irrigated land and the number of ranches in production also grew, which brought about increased agricultural production and livestock production. Consequently, the net production value rose, which led to more investments in local services and infrastructure, which attracted a larger population. As before, population growth led to an increase in the amount of irrigated land and the number of ranches in production.

There were two negative feedback loops, and both were related to environmental constraints. As the amount of irrigated land in production increased, the availability of fertile soil declined. With less availability of fertile soil, the capacity to increase the amount of irrigated land in production declined. Likewise, as livestock practice (livestock production) increased, the availability and quality of rangelands to support grazing (availability of rangelands) decreased.

Market prices varied the profitability of agricultural and livestock products. Rainfall changed the carrying capacity of rangelands, which represented the area required to support livestock without damaging natural resources. The carrying capacity declined as rainfall decreased. Therefore, drought periods resulted in sharp decreases in livestock production (cattle and goats). Hurricanes,
Table 2. Feedback loops and their signs.

\begin{tabular}{lc}
\hline \hline Loop & Sign \\
\hline $\begin{array}{l}\text { Population + Services and infrastructure + Population } \\
\text { Irrigated land + Agricultural production + Profitability of }\end{array}$ & + \\
agriculture + Irrigated land & + \\
$\begin{array}{l}\text { Ranches + Livestock production + Profitability of livestock }+ \\
\text { Ranches }\end{array}$ & + \\
$\begin{array}{l}\text { Irrigated land + Local employment offer + Population + Irrigated } \\
\text { land }\end{array}$ & + \\
$\begin{array}{l}\text { Ranches + Local employment offer + Population + Ranches } \\
\text { Irrigated land + Agricultural production + Net production value + }\end{array}$ & + \\
$\begin{array}{l}\text { Services and infrastructure + Population + Irrigated land } \\
\text { Ranches + Livestock production + Net production value + Services }\end{array}$ & + \\
$\begin{array}{l}\text { and infrastructure + Population + Ranches } \\
\text { Irrigated land - Availability of fertile soils + Irrigated land }\end{array}$ & - \\
$\begin{array}{l}\text { Livestock production }- \text { Availability of rangelands + Livestock } \\
\text { production }\end{array}$ & - \\
\hline
\end{tabular}

the other extreme weather event, also affected livestock production by increasing livestock mortality.

Although certain variables and ecological processes such as hydrogeological dynamics, biodiversity associated with land use, effects of fires and hurricanes on irrigated land, and soil salinization are important in the real system, they were not covered in our model. We ruled out these variables because they were not related directly or indirectly to the depopulation process for the study period. 
Fig. 6. The causal diagram of the underlying system structure. The diagram and the feedback loops are explained in the text. The main variables of the system are marked in blue with larger letters. Environmental limits are depicted in green. The external conditions or forcing functions are marked in orange. Blue arrows are negative feedback loops. Green arrows are positive feedback loops (virtuous cycles). The feedback loops associated with agriculture are larger because they have a heavier relative weight.

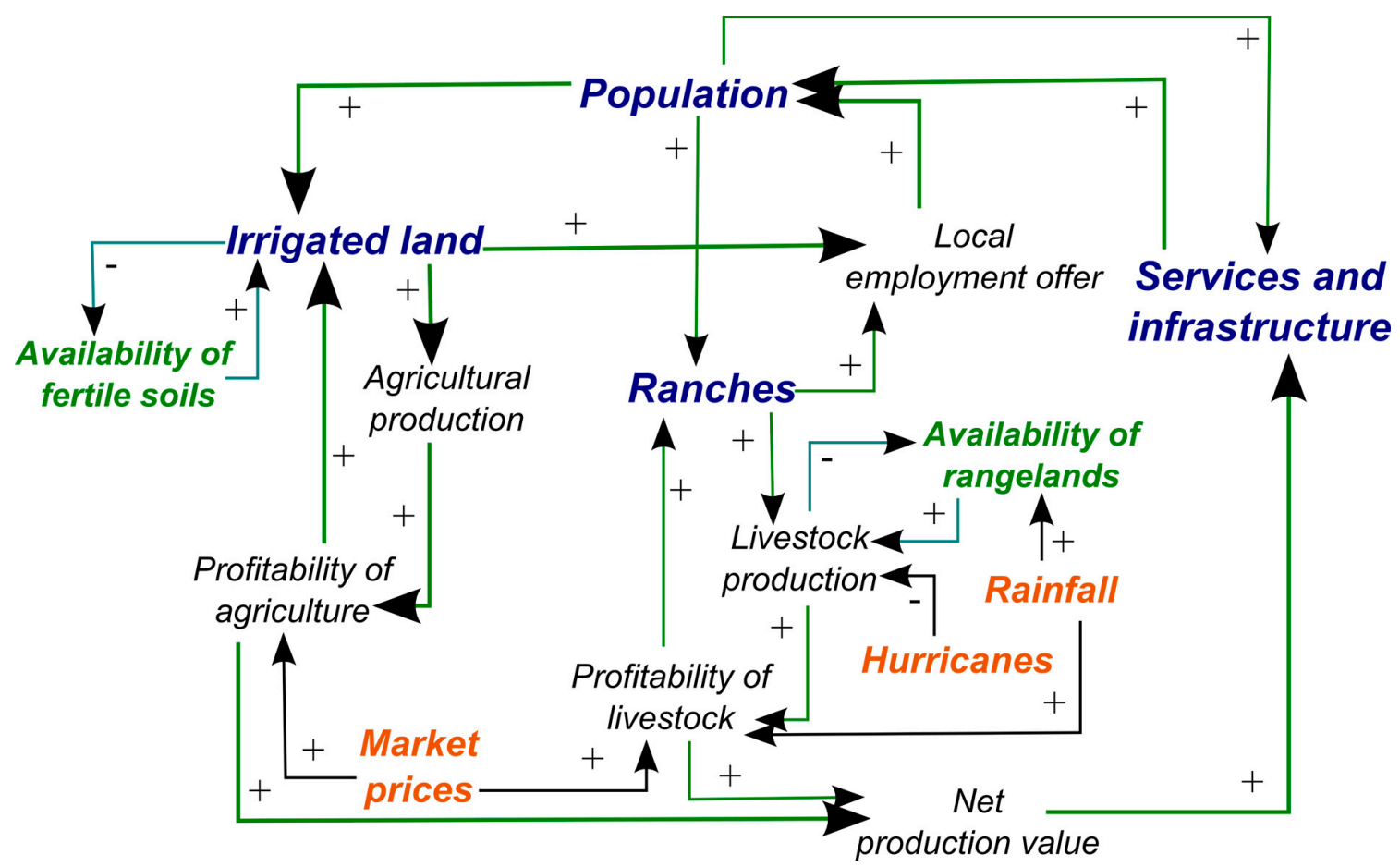

According to this structure, we expected the growth of the population and economic activities to continue until their environmental constraints occurred. Thus, a basal emigration flow of population excess would occur. This expected behavior agreed with the real system dynamics for the 1900-1940 period, when the population reached its peak for the study period. However, some changes had to occur to reverse the dynamics to the observed decline. The analysis of the historical trends inside and outside the oasis of Comondú provided us with the answers.

\section{Historical trends and reference mode of the main system variables}

We divided the study period into four stages to more easily identify changes and possible drivers:

\section{The Golden Age (1900-1940)}

The traditional livelihood in the oasis of Comondú was based on irrigated agriculture, complemented by ranching. The entire area devoted to irrigated land was used for production ( $80 \mathrm{ha}$ ). We identified 92 orchards related to 75 producers, which had an average size of 1 ha (0.3-2.4 ha). Ranching was concentrated on the private lands in the surroundings (37,000 ha). We estimated an initial number of 38 occupied ranches in 20 private properties, which had an average size of 1840 ha (52-4900 ha). While irrigated land depended on the groundwater that emerged from several springs, ranching relied on rainfall supplies. The availability of water on irrigated land did not change during the historical period, not even in times of drought. The maximum flow was
72.66 liters per second (see more about the water flows and quality in Wurl et al. 2013, Gámez et al. 2014). The main agricultural products were date palms, sugar cane, grapes, figs, olives, other fruit trees, cereals, and vegetables (see more about the agrobiodiversity in de Granade and Nabhan 2013). We estimated the average agricultural production was about 2.7 tons per hectare. Livestock activity was based mainly on cattle. Traditionally and locally processed products included wine and sweets derived from sugar cane. Two local institutions for irrigation management ensured irrigation system functioning, including water distribution, infrastructure maintenance, monitoring tasks, and penalties for violations. In order to overcome difficulties from erratic rainfall, ranchers adopted some strategies: rotating grazing, selling surplus animals, and importing hay.

The oasis of Comondú played a central role in the economy and development of BCS. It was the municipality seat of Comondú. The oasis had numerous shops, professional skills (tailoring, blacksmithing, carpentry), and a good provision of public services (schools, medical clinic, post office, telegraph), and most commodities consumed and produced locally, while surpluses were exported to urban centers in the same state and to other parts of Mexico, such as Mazatlán and Guadalajara. This stage was characterized by a growth in the oasis' population, economy, and production, and a high degree of self-sufficiency. Although, it was a time with more social inequality, and there were nearly 1000 inhabitants, only 20 families owned most of the productive land. 
The Fall of Traditional Livelihood (1940-1960)

In the late 1940s, Mexico was concerned about colonizing the territory of BCS to avoid a possible invasion from the United States (Romero 1983, Urciaga 2008). The first attempt was made in 1941, with the agricultural colony named "María Auxiliadora," which failed after 4 years. This agrarian colonization process was also supported by the policies implemented by Manuel Avila Camacho, President of Mexico for the 1940-1946 period. He undertook various commitments to help Mexico follow a path of economic growth that was consistent with that of the United States. One of these commitments was an agricultural research program, known worldwide as the "Green Revolution" (Perfecto et al. 2009). Since 1949, strong successful agricultural modernization, supported by groundwater pumping, has occurred (Fig. 7). The municipality seat of Comondú was transferred to the new agricultural valley of Santo Domingo, first named as "El Crucero," and as "Ciudad Constitución" after 1971.

Fig. 7. The external agricultural area in Baja California Sur (BCS) versus the irrigated land in the oasis of Comondú. The orange line indicates the external agriculture; green points denote irrigated land. Source: Urciaga (2008), in-depth interviews, and GIS (fieldwork).

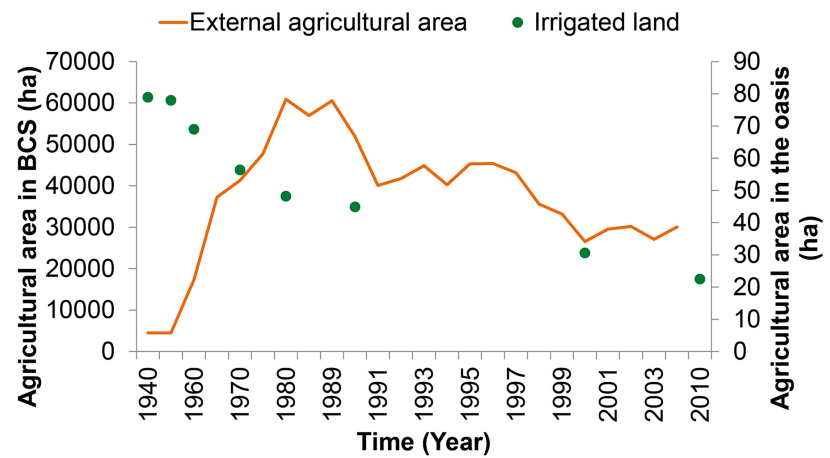

In the oasis of Comondú, agriculture on irrigated land was gradually abandoned (Fig. 7). The oasis changed from selling products to the valley of Santo Domingo to buying the products produced in the valley of Santo Domingo. The new capital of the municipality and the small cities in the state acted as poles that attracted the inhabitants of Comondú who sought educational and professional opportunities, and a new lifestyle.

\section{A New Hope (1960-1980)}

The traditional agriculture of the oasis continued to decline in size and production terms, and suffered from poor access to distant markets. Local institutions for irrigation management collapsed.

The new Transpeninsular Highway, the most important road on the peninsula, bypassed the oasis and left it relatively isolated. Tourism was sponsored and developed by the federal government in coastal areas. Comondú was essentially marginalized. Both public and private services declined (Fig. 8): i.e., public services like schools, post offices, and telegraphs, and private services like local shops, professional skills, community works, and local institutions.
Fig. 8. Qualitative representation of the historical trend of public and private services. The violet line marks public services, including education, medical and religious services, post office, telegraphs, public telephone, electricity and water, transport, administration, and security. The pink line indicates private services, including local shops, professional skills, local institutions, community works, and local festivities. Source: indepth interviews.

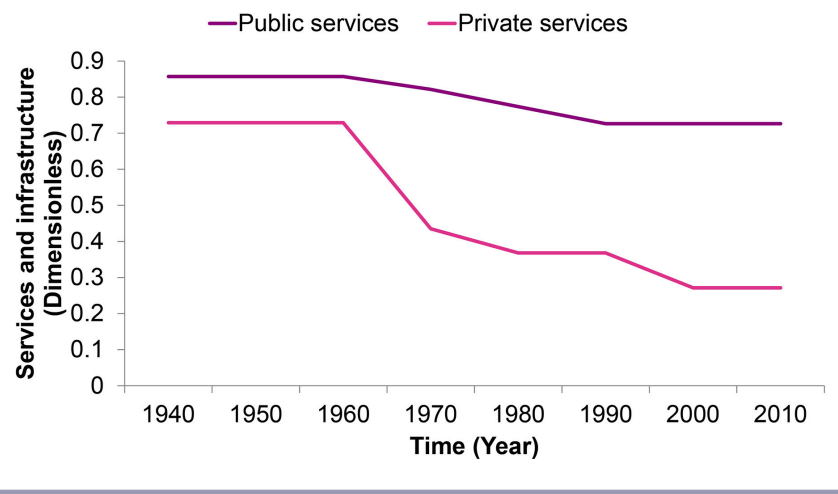

Livestock activity became the main economic activity of the oasis, starting with cattle, and then with goats, which were introduced after the 1950s after goat herding had been successful in nearby oases. One of the keys to the goat herding success was the profit made from sales of young goats in October and January (we estimated the birth of one young goat per adult goat per year), and from the production of cheese every 2 weeks from October through May in wet years and from October to March in dry years. We estimated goat cheese production was about $21 \mathrm{~kg}$ per goat in wet years and $11 \mathrm{~kg}$ per goat in dry years. Goat products were marketed in other parts of Mexico, such as Monterrey, Nuevo León, and Sinaloa, through intermediary merchants. In 1968, the "Ejido Comondú" was created, which provided 70,000 ha of common lands to landless people (a list of 60 "ejidatarios" or ejido members was registered). This was a new local institution for managing rangeland and temporary water sources in a common pool resource in dry lands.

Between the 1970s and 1980s, ranching reached its peak production, and supported more than 10,000 goats and the largest number of families (about 100) that lived on ranches (Fig. 9). Each rancher could handle herds that averaged 133 goats and 100 cattle. The greater the size of the herd, the greater the labor needed.

This stage was characterized by economic alleviation and a more equitable distribution of resources. With nearly 500 inhabitants, approximately 80 families owned productive lands (60 owners of common lands, and 20 owners of private lands).

The Age of Uncertainty (1980-2010)

As Fig. 10 shows, hurricanes and droughts have been frequent disturbances in the history of this system. There is no significant evidence for a change in the frequency and intensity of these events over time. Yet during this stage, the consequences of social weakening became more evident than ever. In addition, dependence on livestock activity destabilized the system dynamics 
Fig. 9. Livestock activity in the oasis of Comondú. Orange triangles denote occupied ranches, red squares are cattle, and blue points are goats. Dashed arrows indicate the introduction of goats and the creation of the Ejido Comondú; dotted lines indicate the period with the largest number of occupied ranches and heads of cattle and goats (1970-1980). The periods when ranches were abandoned are indicated with black arrows. Source: The 1962 General and Agricultural Census of the Official Gazette of the Government of the Territory of Baja California Sur (1968), and in-depth interviews.

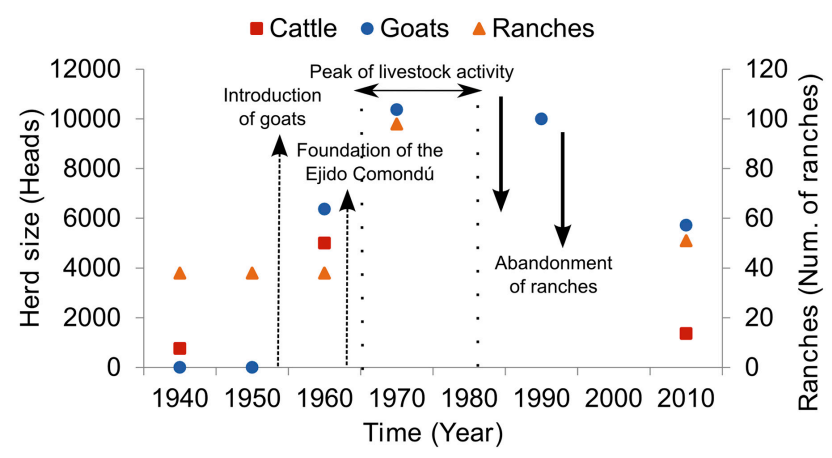

Fig. 10. Rainfall, droughts, and hurricanes. The years with rainfall that was less than the average annual rainfall rate are considered drought years. Hurricanes are indicated with dotted lines. The official register of hurricanes in Baja California Sur started in 1966. Hurricane wind categories are as follows: H5 (> 135 knots), H4 (114-135 knots), H3 (96-113 knots), H2 (83-95 knots), H1 (64-82 knots), TS (tropical or subtropical storm; 34-63 knots), TD (tropical depression; < 34 knots), and ET (extra-tropical storm, varies). Source: Climatic data (19402010) from Weather Station 3008 (San José de Comondú) of the National Water Commission of Mexico, and Historical Hurricane Tracks from the National Oceanic and Atmospheric Administration (https://coast.noaa.gov/hurricanes/)

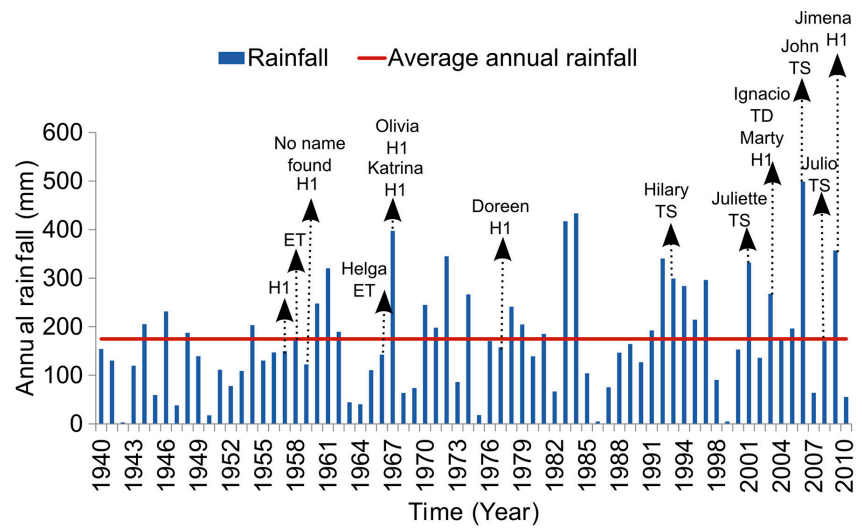

once again. Despite the strategies previously mentioned (rotating grazing, selling surplus animals, and importing hay), droughts led to losses of up to $62 \%$ of goats and $40 \%$ of cattle in 1 year.
Droughts also attracted large predators: coyotes, cougars, and bobcats. In 1 year, a rancher could lose $20 \%$ of their goats and $10 \%$ of their cows to predators. Diseases were also more common. Three hurricanes seriously affected livestock production in 2001, 2006, and 2009, and led to further losses of goats and cattle. Hurricane Jimena was the most intense, and ranchers claimed losses of $2-67 \%$ of their goats.

From 1986 to 2010, more than 50 families abandoned their ranches and emigrated because of devastating effects of hurricanes and droughts on livestock (Fig. 9). This coincided with a difficult period in Mexico's economy as the Mexican peso devaluated internationally, which was known as the "Tequila crisis," and it affected prices of commodities.

The regional market prices of the main products from the oasis have shown increased profitability for livestock products versus agricultural products since the middle of the 1950s. However, prices of livestock products reflected the greatest fluctuations (Fig. 11).

Fig. 11. Regional market prices of the main agricultural and livestock products of the oasis (constant prices with 1975 taken as the base year). The blue line represents the price of agricultural products (dates, sugar cane, and grapes), and the red line denotes the price of livestock products (cattle, goats, and goat's cheese). Source: 1929-1998: historical statistics of Baja California Sur (SEDESOL 2002a, b, 2003); 1940-1998: historical statistics of Mexico Vol.1 (INEGI 2009); 1980-2010: data from the Agricultural Information System Consultation (SIACON) (http://www.siap.gob.mx/ optestadisticasiacon2012parcialsiacon-zip/)

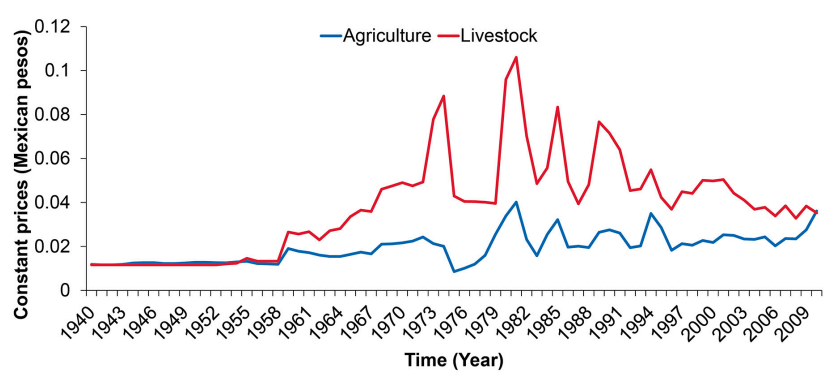

In 2010, when we did most of the fieldwork, only $30 \%$ of irrigated lands were used for production (24 ha), and livestock numbers continued to decline from lack of rain. We estimated that only 51 ranches were occupied. The accumulation of plant remains in canals and plots led to three major wildfires in the oasis since 1980. With Hurricane Jimena, orchards were flooded, and production and some soils were lost. We were able to verify the presence of salt crusts in $12 \%$ of orchard soil. Instability, uncertainty, social deterioration, and weakening of adaptability characterized this last stage.

Fig. 12 summarizes the most relevant and severe socioeconomic and socio-political changes on higher scales during the historical period. The changes at the regional level heavily influenced the dynamics at the local scale, but some of these changes were a response of decisions and processes that happened much at higher 
Fig. 12. Socioeconomic changes on higher scales. The changes on the global-national scale are located on the blue stripe; regional and local changes are on the violet stripe.

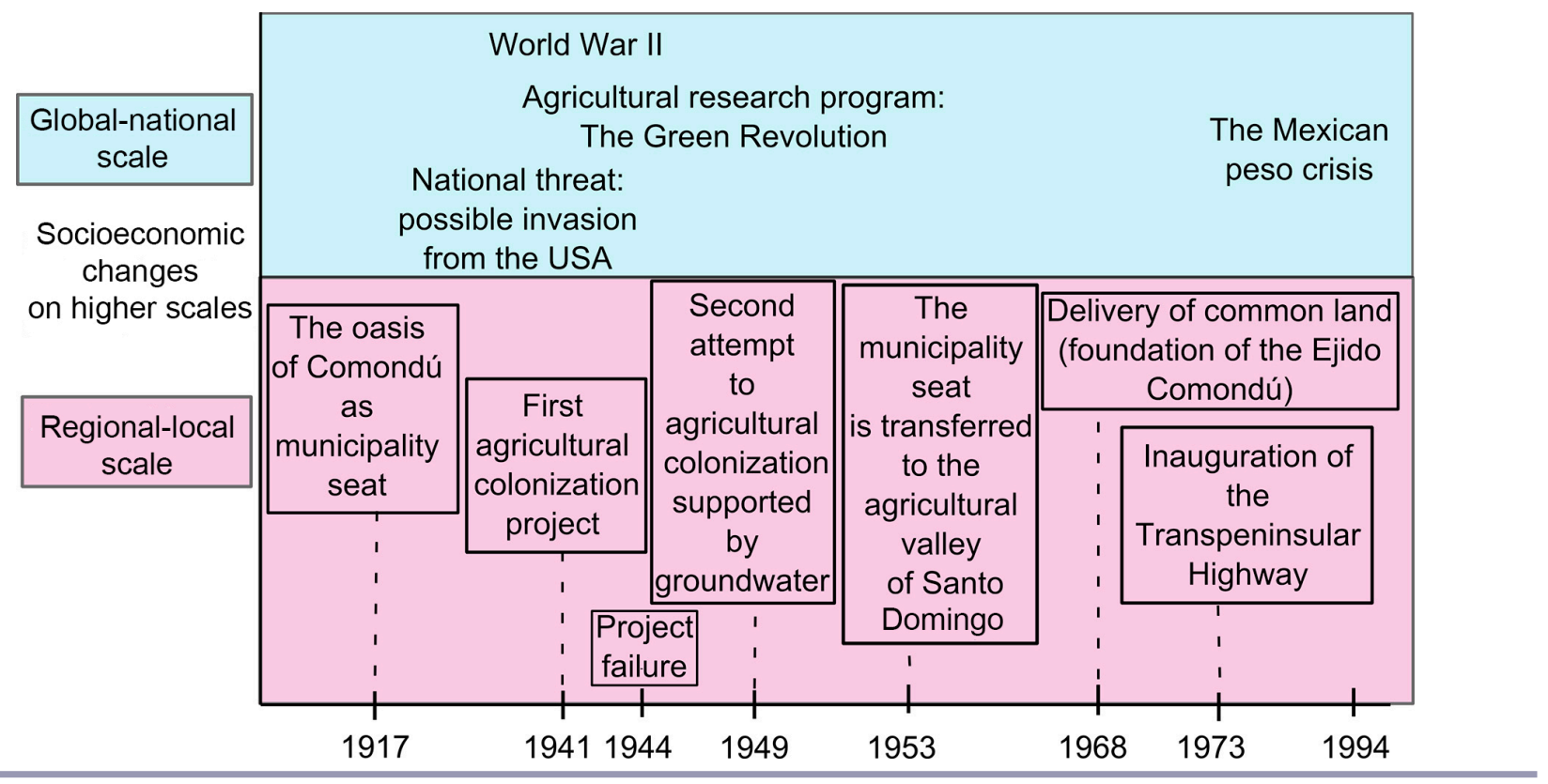

scales. The agricultural development in BCS was related to the necessity to colonize the territory, and with the Green Revolution, a global process that characterized the post-World War II period. This timeline scheme helps show the interconnection between scales.

\section{Social-ecological changes and effects on resilience}

As shown in Fig. 6, the underlying structure of this system was dominated by positive feedback loops. Their tendency can be slowed down by specific limits to growth: availability of fertile soil and rangelands, in this case. However, the real system behavior indicated not only slowing growth but a reverse tendency to decline. Only the effect of external conditions or forcing functions could change the system behavior in this way. Into the causal loop diagram we integrated the main socioeconomic and sociopolitical changes in BCS during the study period (Fig. 13).

The profitability of agriculture suffered the effects of external competition, which has been defined by the development of external agriculture and socio-political relocation. Socio-political relocation represents the change in the municipality seat, the marginalization caused by the Transpeninsular Highway, and the deviation of public investment to other urban centers of BCS. Development of external agriculture represents the growth of modern and technician agriculture in the agricultural valleys of the state. This led to a displacement of the traditional production in the oasis to regional and national markets, which favored new export-oriented production.

Services were also affected by socio-political relocation because it meant less public investment in the oasis. The creation of the Ejido Comondú implied the delivery of 70,000 ha of common land; this reinforced the rise in livestock activity.

We identified two types of structural changes in the system: (1) the direction change in positive feedback loops from virtuous cycles to vicious cycles, and (2) a change in the relative weight of some variables and interactions.

Development of external agriculture and socio-political relocation reversed the direction of the positive feedback loops associated with agricultural activity and services in the oasis. The profitability drop caused irrigated land to decrease, which reduced the local employment offer and the economy of the oasis (net production value). The drop in public investment encouraged the disappearance of some public services and a deteriorated public infrastructure. The basal emigration flow was reinforced. The depopulation process weakened local institutions until they collapsed, and caused social disarticulation.

With agriculture declining, the resident population increased the relative weight of its ranching activity, firstly with cattle, and after the success in nearby oases, with goats. This change in the relative importance of productive activities was reinforced by the delivery of common lands, known as the creation of the Ejido Comondú.

Goat herding alleviated the economic situation of the oasis by increasing economy (net production value) and the local employment offer. However, cattle, and especially goats, are vulnerable to extreme weather events like droughts (which depend on rainfall) and hurricanes, which are relative frequent disturbances in the lifetime of the SES. Drought periods reduce the carrying capacity of rangelands and increase livestock mortality. Droughts also reduce the profitability of cattle due to imports of hay and other food supplements. Hurricanes provide the system with water, but also markedly increase livestock mortality. This means that the main economic activity of the oasis underwent significant fluctuations, which spread to the rest of the system, and the economy and local employment oscillated. These were unfavorable conditions for the population. Uncertainty and instability were factors that encouraged migration to other places that offered better conditions. 
Fig. 13. The causal diagram with the effects of new external conditions. These new external conditions are marked in red. In this case, the feedback loops associated with livestock activity are larger because they have a heavier relative weight in the system. The system's positive feedback loops were changed to red because it emphasizes the change in dynamics from growth to a reduction, and now they are vicious cycles.

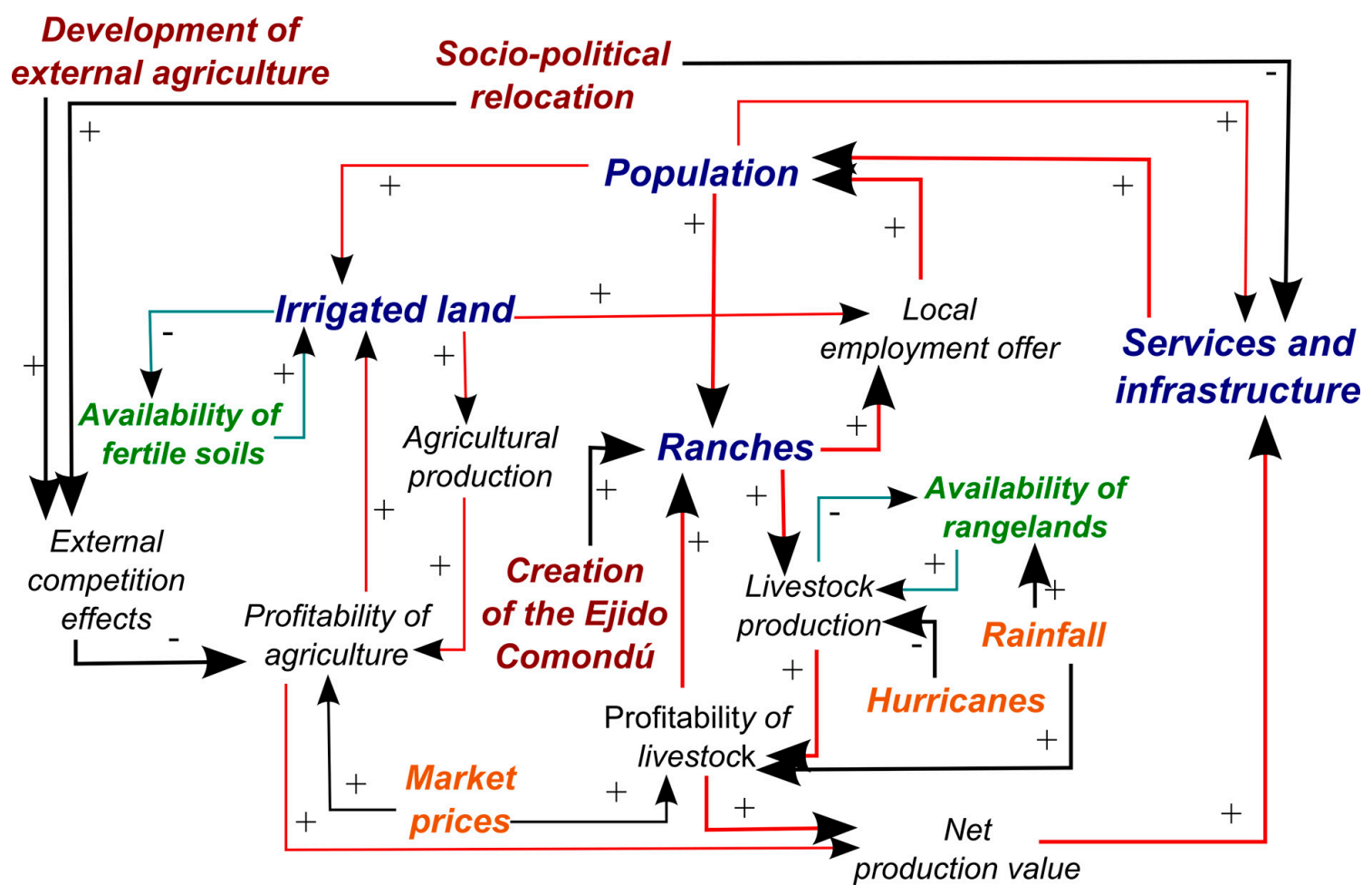

In relation to changes in SES resilience, in the first stage ("the Golden Age") when the system was based on traditional agriculture, it was resilient to frequent disturbances like hurricanes and droughts. However, the system was not prepared for the slow persistent changes on higher scales represented by a set of political and economic changes. This caused traditional agriculture to decline and emigration to increase, both of which weakened the SES. The system adapted to new conditions by increasing the livestock activity role. Nevertheless, this change led to maladaptation because the SES became vulnerable to frequent disturbances, hurricanes, and droughts. The depopulation process continued, and the system is now unable to respond to new disturbances, and the ability to adapt to them is seriously limited.

In the SES of the oasis of Comondú, exogenous drivers are responsible for the endogenous changes that have led system dynamics to collapse. The depopulation process (an endogenous driver) was the effect of the slow, persistent changes on the higher scales but was also the cause of the deterioration and decline of this SES.

\section{DISCUSSION AND GROUNDED SPECULATION}

We have presented a qualitative model of a declining small-scale, long-lived SES, using the conceptualization process of the system dynamics approach. Our modeling approach has been useful for hypothesizing the structure of this SES, and for identifying the main drivers that triggered the dynamics toward collapse, deepening into the causal and feedback relationships, which other qualitative methods (e.g., adaptive cycles) do not perform well (Abel et al. 2006). As other authors have highlighted about the importance of the conceptualization process (Forrester 1992, Jørgensen and Bendoricchio 2001, Luna-Reyes and Andersen 2003), this modeling step permitted us to gather a rich set of qualitative and quantitative information that enables us to advance in the future modeling steps: quantitative modeling (including model evaluation), and exploration of future management scenarios. In addition, our methodological approach, especially the participant observation, has contributed to building a strong confidence relationship with local actors, which could support possible future participatory processes.

We qualitatively analyzed the structure and dynamics of the oasis of Comondú, a small-scale, long-lived SES, whose behavior has changed from well-functioning to decline. Analyzing the underlying structure of the system revealed that the system should grow until its environmental limits are reached, and then it should continue with relatively stable dynamics. However, the historical trends and data observed indicated a qualitative change in system dynamics. Only external drivers, changes on higher scales, could reverse the tendency from growth to reduction. The analysis of the effects of these changes on the system structure showed that performing external agriculture and a socio-politic relocation in BCS caused a severe depopulation process in the oasis. Likewise, this process dragged the entire system to display a tendency to collapse, which reversed the positive feedback loops from growth 
to reduction. The tendency of this SES to collapse was triggered by exogenous factors but was also maintained by the endogenous structure. The resilience of this SES suffered with these structural changes. One of these changes was to increase the relative weight of livestock activity in the economy of the oasis. This can be seen as an adaptation to the new external conditions, but it worsened the system's resilience and increased its vulnerability to extreme weather events. This situation is especially important because extreme weather events (i.e., hurricanes and droughts) might become more frequent due to climate change.

Despite the usefulness of qualitative models (Downing et al. 2014, Barber et al. 2015, Martone et al. 2017), we are aware of their limitations; thus, the results we have presented should be read cautiously. Our qualitative model does not include stocks and flows, and the deriving dynamic consequences from the causal loop diagram discussed could give us misleading conclusions (Vennix 1996). For this reason, the qualitative model constitutes only a hypothesis about the system structure. Building the quantitative dynamic simulation model is the necessary following step to test the hypothesis. In any case, our results agree with not only the theories of collapse, where a drop in human capital could lead SESs to collapse (Motesharrei et al. 2014), but also with the theory of adaptive cycles, where collapse is preceded by loss of capital and loss of resilience (Holling 1987, 2001, Walker et al. 2006). Although the main drivers of collapse in our case study were exogenous, we considered that the inequity of resource distribution, especially land distribution, in the SES of the oasis of Comondú was a vulnerability cause that acted as a driving factor that increased the emigration flow when faced with new external conditions (Motesharrei et al. 2014). However, the scarcity of detailed land tenure data for the study period hindered the quantification of changes in land tenure over time.

The qualitative studies of SESs suggested that the effects of slow, persistent changes on higher scales (changes in socioeconomic conditions or technology) may lead to a relatively smooth transition of the SES, unlike top-down interventions (imposed changes of institutional arrangements) that hinder the SES' adaptations (Janssen et al. 2007). Our study suggests that the transition driven by effects of slow, persistent changes on higher scales could lead to a long-term SES maladaptation and could increase the vulnerability of the SES to frequent disturbances in the system.

Depopulation processes have undermined the traditional way of life in SESs and their local institutions because younger, healthier, and more educated people often migrate from communities (Reichert 1981, Stasiak 1992, Binford 2003, Collantes 2007). This selective migration involves loss of needed human and social capital from small-scale SESs when an endogenous approach to rural development is encouraged (Stockdale 2004). This is a critical point because rural development is necessary to revitalize and maintain these long-lived SESs, but they need human and social capital to achieve this.

In the SES of the oasis of Comondú, according to the roots of the depopulation problem, it seems that an improvement in the conditions and quality of life (local employment, services, economic growth, and stability) could convince migrant families to return or could attract new young people who are drawn to a different lifestyle. There is a worldwide countermovement of repopulation of rural small-scale, long-lived SESs (Buller and Hoggart 1994, Boyle and Halfacree 1998, Camarero et al. 2009), which has possibly been motivated or reinforced by the global financial crisis. The reorientation of regional policies to the oases of BCS (e.g., support for economic diversification, support to add value to local products, support to develop new market channels into organics, improve the provision of public services), and strengthening and restructuring the local communities of these oases (social networks, local institutions) could change current trends. However, we must identify and collect concrete policy measures and management options (suggested by local actors), and then integrate them into the dynamic simulation model to assess which combination of measures more efficiently reduces the depopulation process or even reverses it, among other possible management goals. In this way, the dynamic simulation model will be converted into a useful tool to more efficiently guide decision-making processes and the use of resources (MartínezFernández 2000, Pérez et al. 2012, Vidal 2013, Banos-González et al. 2016).

The results of this study and the development of the management model could serve as a methodological basis for other oases of the BCS or similar SESs, but in each case, modifications will be necessary to adapt the model to specific problems and local conditions (Jørgensen and Bendoricchio 2001).

The study of small-scale, long-lived SESs could assist in solving their specific problems in order to maintain them in their functional and desired states. Their conservation in the long-term could catalyze a transition in the way our society relates to the environment, reconciling the use of natural resources with biodiversity conservation and food security in a sustainable way. Long-lasting SESs are examples of more sustainable models of life compared to our globalized industrial society. They promote biodiversity, and possess a set of knowledge and practices that allow them to cope with perturbations and sustain yields without use of agrochemicals (Altieri 2009). They are not perfect, and they are suffering many changes. However, we can see them as a kind of "seeds" for a new global change. Hundreds of experiences in Latin America and Africa have shown how the traditional ecological knowledge of these SESs could be enriched by innovations and ecological principles to improve productiveness and the efficient use of labor and local resources (Altieri 1999, 2009). The collaboration and cooperation between local communities, NGOs, academics, governments, and citizens in general (as consumers) is necessary to encourage this transition. Successes in local experiences, and their reproduction could have an effect at the global scale.

\section{CONCLUSIONS}

We suggest the use of the system dynamics approach and building management models as a comprehensive and useful tool to address the specific problems of SESs, and assess alternative management options to solve them, avoiding panaceas. We present the first step, the conceptualization process, which provides a rich amount of information about the system under study, allows visualization of the system's hypothesized structure related to the observed behavior (deepening into the causal and feedback relationships), and establishes the basis for quantitative modeling. Our study about the oasis of Comondú (BCS, Mexico), a small-scale, long-lived SES that has lived a dramatic transition 
from well-functioning to decline in recent decades, agrees with collapse theories and adaptive cycles, and identifies a reduction in capital and resilience as signs of the tendency toward collapse. The slow, persistent changes (the development of external agriculture and a socio-politic relocation in BCS) caused a severe depopulation process in the oasis. This process dragged the entire system toward decline. This tendency was triggered by exogenous factors but was maintained by the endogenous structure. In our case study, the effects of slow, persistent changes led to a longterm SES maladaptation, which increased the vulnerability of the system to frequent disturbances (hurricanes and droughts). The conceptual model we presented has limitations because it does not include stocks and flows. Quantitative modeling is the necessary following step to test it. We expect to use the results of the entire research to analyze the system behavior, assess the effects of alternative management options, and support decisionmaking processes for improving local conditions and restoring the system's well-functioning.

Responses to this article can be read online at: http://www.ecologyandsociety.org/issues/responses. $\mathrm{php} / 9176$

\begin{abstract}
Acknowledgments:
We thank Ana Luisa Castillo, Wendi Domínguez, and Jorge Noriega for their support in the field. Pedro Segura supervised the economic data. Aurora Breceda of CIBNOR provided support during the current research stay at CIBNOR. We thank the residents of Comondu for their warm welcome and participation in this research, all the RIDISOS members for their collaboration, and the support of several government agencies of Mexico (INEGI, CONAGUA, SAGARPA, RAN, SEDESOL) by providing official data sets. A. $T$. is the recipient of the doctoral fellowship of the Generalitat Valenciana (BFPI/2009/085), the fellowship abroad of AECID (2010-2011), and the research stay grant at CIBNOR (2014-2016), which was funded by the Secretaria de Relaciones Exteriores of Mexico and Santander Bank. The research project was funded by Consejo Nacional de Ciencia y Technología (CONACYT grant CB-2008-01/98484). The preparation of this article is supported by SEMARNAT-CONACYT-2014-01 (project 249464).
\end{abstract}

\section{LITERATURE CITED}

Abel, N., D. H. M. Cumming, and J. M. Anderies. 2006. Collapse and reorganization in social-ecological systems: questions, some ideas, and policy implications. Ecology and Society 11(1):17. http://dx.doi.org/10.5751/es-01593-110117

Anderies, J. M. 2000. On modeling human behavior and institutions in simple ecological economic systems. Ecological Economics 35:393-412. http://dx.doi.org/10.1016/S0921-8009 (00)00221-4

Altieri, M. A. 1999. Applying agroecology to enhance the productivity of peasant farming systems in Latin America. Environment, Development and Sustainability 1:197-217. http:// dx.doi.org/10.1023/A:1010078923050
Altieri, M. A. 2009. Agroecology, small farms, and food sovereignty. Monthly Review 61 (3):102-113. http://dx.doi. org/10.14452/mr-061-03-2009-07 8

Arriaga, L., and R. Rodríguez-Estrella. 1997. Los Oasis de la Península de Baja California. CIBNOR, La Paz, Mexico.

Banos-González, I., J. Martínez-Fernández, and M. A. EsteveSelma. 2015. Dynamic integration of sustainability indicators in insular socio-ecological systems. Ecological Modelling 306:130144. http://dx.doi.org/10.1016/j.ecolmodel.2014.08.014

Banos-González, I., J. Martínez-Fernández, and M. A. EsteveSelma. 2016. Using dynamic sustainability indicators to assess environmental policy measures in biosphere reserves. Ecological Indicators 67:565-576. http://dx.doi.org/10.1016/j.ecolind.2016.03.021

Baral, N., M. J. Stern, and J. T. Heinen. 2010. Growth, collapse, and reorganization of the Annapurna Conservation Area, Nepal: an analysis of institutional resilience. Ecology and Society 15 (3):10. http://dx.doi.org/10.5751/es-03534-150310

Barber, M., S. Jackson, J. Dambacher, and M. Finn. 2015. The persistence of subsistence: qualitative social-ecological modeling of indigenous aquatic hunting and gathering in tropical Australia. Ecology and Society 20(1):60. https://www.ecologyandsociety. org/vol20/iss1/art60/

Baur, I., and C. R. Binder. 2015. Modeling and assessing scenarios of common property pastures management in Switzerland. Ecological Economics 119:292-305. http://dx.doi.org/10.1016/j. ecolecon.2015.09.019

Becker, H., and B. Geer. 1957. Participant observation and interviewing: a comparison. Human Organization 16:28-32. http://dx.doi.org/10.17730/humo.16.3.k687822132323013

Bert, F. E., G. P. Podestá, S. L. Rovere, A. N. Menéndez, M. North, E. Tatara, C. E. Laciana, E. Weber, and F. R. Toranzo. 2011. An agent based model to simulate structural and land use changes in agricultural systems of the Argentine pampas. Ecological Modelling 222:3486-3499. http://dx.doi.org/10.1016/j. ecolmodel.2011.08.007

Binford, L. 2003. Migrant remittances and (under) development in Mexico. Critique of Anthropology 23:305-336. http://dx.doi. org/10.1177/0308275X030233004

Boyle, P., and K. Halfacree. 1998. Migration into rural areas. Wiley and Sons, Chichester, United Kingdom.

Brander, J. A., and M. S. Taylor. 1998. The simple economics of Easter Island: a Ricardo-Malthus model of renewable resource use. American Economic Review 88(1):119-138.

Bueno, N., and X. Basurto. 2009. Resilience and collapse of artisanal fisheries: a system dynamics analysis of a shellfish fishery in the Gulf of California, Mexico. Sustainability Science 4:139-149. http://dx.doi.org/10.1007/s11625-009-0087-Z

Buller, H., and K. Hoggart. 1994. International counterurbanization: British migrants in rural France. Aldershot, Avebury, UK.

Camarero, L., F. Cruz, M. González, J. A. del Pino, J. Oliva, and R. Sampedro. 2009. La población rural de España. De los desequilibrios a la sostenibilidad social. Fundación La Caixa, Barcelona, Spain. 
Cariño, M. 2001. La oasisidad, núcleo de la cultura sudcaliforniana. Gaceta Ecológica 60:57-69.

Cariño, M., A. Breceda, A. Ortega, and L. Castorena, editors. 2013. Evocando el edén. Conocimiento, valoración y problemática del Oasis de Los Comondú. Icaria editorial S. A., Barcelona, Spain.

Cariño, M., and A. Ortega, editors. 2014. Oasis sudcalifornianos. Para un rescate de la sustentabilidad local. Editorial Universidad de Granada, Granada, Spain.

Cocks, K. D. 2003. Deep futures: our prospects for survival. University of New South Wales Press, Sydney, Australia.

Collantes, F. 2007. The decline of agrarian societies in the European countryside: a case study of Spain in the twentieth century. Agricultural History 81:76-97. http://dx.doi.org/10.3098/ $\underline{\text { ah.2007.81.1.76 }}$

Costanza, R., and M. Ruth. 1998. Using dynamic modeling to scope environmental problems and build consensus. Environmental Management 22:183-195. http://dx.doi.org/10.1007/s002679900095

Coyle, G. 2000. Qualitative and quantitative modelling in system dynamics: some research questions. System Dynamics Review 16:225-244. http://dx.doi.org/10.1002/1099-1727(200023)16:3<225:: AID-SDR 195>3.0.CO;2-D

Dale, V. H., R. V. O'Neill, M. Pedlowski, and F. Southworth. 1993. Causes and effects of land-use change in central Rondonia, Brazil. Photogrammetric Engineering \& Remote Sensing 59:9971005.

de Grenade, R. , and G. P. Nabhan. 2013. Baja California peninsula oases: an agro-biodiversity of isolation and integration. Applied Geography 41:24-35. http://dx.doi.org/10.1016/j. apgeog.2013.03.008

Downing, A. S., E. H. van Nes, J. S. Balirwa, J. Beuving, P. O. J. Bwathondi, L. J. Chapman, I. J. M. Cornelissen, I. G. Cowx, K. P. C. Goudswaard, R. E. Hecky, J. H. Janse, A. B. G. Janssen, L. Kaufman, M. A. Kishe-Machumu, J. Kolding, W. Ligtvoet, D. Mbabazi, M. Medard, O. C. Mkumbo, E. Mlaponi, A. T. Munyaho, L. A. J. Nagelkerke, R. Ogutu-Ohwayo, W. O. Ojwang, H. K. Peter, D. E. Schindler, O. Seehausen, D. Sharpe, G. M. Silsbe, L. Sitoki , R. Tumwebaze, D. Tweddle, K. E. van de Wolfshaar, H. van Dijk, E. van Donk, J. C. van Rijssel, P. A. M. van Zwieten, J. Wanink, F. Witte, and W. M. Mooij. 2014. Coupled human and natural system dynamics as key to the sustainability of Lake Victoria's ecosystem services. Ecology and Society 19 (4):31. http://dx.doi.org/10.5751/ES-06965-190431

Duffy, S. B., M. S. Corson, and W. E. Grant. 2001. Simulating land-use decisions in the La Amistad Biosphere Reserve buffer zone in Costa Rica and Panama. Ecological Modelling 140:9-29. http://dx.doi.org/10.1016/S0304-3800(01)00266-6

Evans, T. P., A. Manire, F. de Castro, E. Brondizio, and S. McCracken. 2001. A dynamic model of household decisionmaking and parcel level landcover change in the eastern Amazon. Ecological Modelling 143:95-113. http://dx.doi.org/10.1016/ $\underline{\mathrm{S} 0304-3800(01) 00357-\mathrm{X}}$

Food and Agriculture Organization of the United Nations (FAO). 2014. The state of food and agriculture: innovation in family farming. FAO, Rome, Italy.
Forrester, J. W. 1958. Industrial dynamics: a major breakthrough for decision makers. Harvard Business Review 36:37-66.

Forrester, J. W. 1961. Industrial dynamics. Pegasus Communications, Waltham, Massachusetts, USA.

Forrester, J. W. 1969. Urban dynamics. Pegasus Communications, Waltham, Massachusetts, USA.

Forrester, J. W. 1973. World dynamics. Pegasus Communications, Waltham, Massachusetts, USA.

Forrester, J. W. 1992. Policies, decisions and information sources for modeling. European Journal of Operational Research 59:4263. http://dx.doi.org/10.1016/0377-2217(92)90006-U

Forrester, J. W., and P. Senge. 1980. Tests for building confidence in system dynamics models. TIMS Studies in the Management Sciences 14:209-228.

Gámez, A. E., J. Wurl, and J. C. Graciano. 2014. Disponibilidad y uso del agua en el oasis de los Comondú, Baja California Sur: retos y oportunidades para el desarrollo rural. Región y sociedad 60:165-190.

Happe, K. 2005. Agent-based modeling and sensitivity analysis by experimental design and metamodelling: an application to modeling regional structural change. In: XIth International Congress of the European Association of Agricultural Economists, the Future of Rural Europe in the Global Agri-Food System. Copenhagen, Denmark.

Holling, C. S. 1987. Simplifying the complex: the paradigms of ecological function and structure. European Journal of Operational Research 30:139-146. http://dx.doi.org/10.1016/0377-2217 (87)90091-9

Holling, C. S. 2001. Understanding the complexity of economic, ecological, and social systems. Ecosystems 4:390-405. http://dx. doi.org/10.1007/s10021-001-0101-5

Instituto Nacional de Estadistica y Geografia (INEGI). 2009. Estadísticas Históricas de México. Vol. 1. Tomo II. Tema 17, precios, México City, México.

Instituto Nacional de Estadistica y Geografia (INEGI). 2011. Marco Geoestadístico Nacional: Localidades geoestadísticas, archivo histórico. [online] URL: http://www.inegi.org.mx/geo/ contenidos/geoestadistica/introduccion.aspx

Janssen, M. A., J. M. Anderies, and E. Ostrom. 2007. Robustness of social-ecological systems to spatial and temporal variability. Society \& Natural Resources 20:307-322. http://dx.doi. org/10.1080/08941920601161320

Jørgensen, S. E., and G. Bendoricchio. 2001. Fundamentals of ecological modelling. Elsevier Science, Oxford, USA.

Lacitignola, D., I. Petrosillo, M. Cataldi, and G. Zurlini. 2007. Modelling socio-ecological tourism-based systems for sustainability. Ecological Modelling 206:191-204. http://dx.doi.org/10.1016/j. ecolmodel.2007.03.034

Li, F. J., S. C. Dong, and F. Li. 2012. A system dynamics model for analyzing the eco-agriculture system with policy recommendations. Ecological Modelling 227:34-45. http://dx.doi. org/10.1016/j.ecolmodel.2011.12.005 
Luna-Reyes, L. F., and D. L. Andersen. 2003. Collecting and analyzing qualitative data for system dynamics: methods and models. System Dynamics Review 19:271-296. http://dx.doi. org/10.1002/sdr.280

Marín, V. H., L. C. Rodríguez, and H. M. Niemeyer. 2012. A socio-ecological model of the Opuntia scrublands in the Peruvian Andes. Ecological Modelling 227:136-146. http://dx.doi. org/10.1016/j.ecolmodel.2011.12.010

Martínez-Fernández, J., M. A. Esteve-Selma, I. Baños-González, F. Carreño, and A. Moreno. 2013. Sustainability of Mediterranean irrigated agro-landscapes. Ecological Modelling 248:11-19. http://dx.doi.org/10.1016/j.ecolmodel.2012.09.018

Martínez-Fernández, J., M. A. Esteve-Selma, and J. F. CalvoSendín. 2000. Environmental and socioeconomic interactions in the evolution of traditional irrigated lands: a dynamic system model. Human Ecology 28:279-299. http://dx.doi.org/10.1023/ A:1007024204961

Martone, R. G., A. Bodini, and F. Micheli. 2017. Identifying potential consequences of natural perturbations and management decisions on a coastal fishery social-ecological system using qualitative loop analysis. Ecology and Society (22) 1:34. https://www.ecologyandsociety.org/vol22/iss1/art34/

Meadows, D. L., W. W. Behrens III, D. H. Meadows, R. F. Naill, J. Randers, and E. K. O. Zahn. 1974. Dynamics of growth in a finite world. Wright-Allen Press, Cambridge, Massachusetts, USA.

Meadows, D. H., D. L. Meadows, J. Randers, and W. W. Behrens III. 1972. The limits to growth. Universe Books, New York, USA.

Motesharrei, S., J. Rivas, and E. Kalnay. 2014. Human and nature dynamics (HANDY): modeling inequality and use of resources in the collapse or sustainability of societies. Ecological Economics 101:90-102. http://dx.doi.org/10.1016/j.ecolecon.2014.02.014

Musacchio, L. R., and W. E. Grant. 2002. Agricultural production and wetland habitat quality in a coastal prairie ecosystem: simulated effects of alternative resource policies on land-use decisions. Ecological Modelling 150:23-43. http://dx.doi. org/10.1016/S0304-3800(01)00459-8

Ostrom, E., M. A. Janssen, and J. M. Anderies. 2007. Going beyond panaceas. Proceedings of the National Academy of Sciences of the United States of America 104:15176-15178. http:// dx.doi.org/10.1073/pnas.0701886104

Pérez, I., A. Tenza, J. D. Anadón, J. Martínez-Fernández, A. Pedreño, and A. Giménez. 2012. Exurban sprawl increases the extinction probability of a threatened tortoise due to pet collections. Ecological Modelling 245:19-30. http://dx.doi. org/10.1016/j.ecolmodel.2012.03.016

Perfecto, I., J. Vandermeer, and A. Wright. 2009. Nature's matrix: linking agriculture, conservation and food sovereignty. Earthscan, London, United Kingdom.

Portela, R., and I. Rademacher. 2001. A dynamic model of patterns of deforestation and their effect on the ability of the Brazilian Amazonia to provide ecosystem services. Ecological Modelling 143:115-146. http://dx.doi.org/10.1016/S0304-3800 (01)00359-3
Randers, J. 1980. Guidelines for model conceptualization. Pages 117-139 in J. Randers, editor. Elements of the system dynamics method. MIT Press, Cambridge, Massachusetts, USA.

Reichert, J. S. 1981. The migrant syndrome: seasonal U.S. wage labor and rural development in Central Mexico. Human Organization 40:56-66. http://dx.doi.org/10.17730/humo.40.1. $\underline{\mathrm{c} 6148 \mathrm{p} 5743512768}$

Richardson, G. P., and A. L. Pugh, III. 1981. Introduction to system dynamics modeling with DYNAMO. Productivity Press, Cambridge, Massachusetts, USA.

Roberts, N., D. F. Andersen, R. M. Deal, M. S. Garet, and W. A. Shaffer. 1983. Introduction to computer simulation: a systems dynamics approach. Addison-Wesley, Boston, Massachusetts, USA.

Romero, R. 1983. Baja California histórica y legendaria. CostaAMIC, Mexico City, Mexico.

Sanga, G. J., and E. D. Mungatana. 2016. Integrating ecology and economics in understanding responses in securing land-use externalities internalization in water catchments. Ecological Economics 121:28-39. http://dx.doi.org/10.1016/j.ecolecon.2015.11.011

Saysel, A. K., T. Barlas, and O. Yenigün. 2002. Environmental sustainability in an agricultural development project: a systems dynamics approach. Journal of Environmental Management 64:247-260. http://dx.doi.org/10.1006/jema.2001.0488

SEDESOL. 2002a. Estadísticas Históricas 1929-1956. Territorio Sur de Baja California. La Paz, Mexico: Gobierno del Estado de Baja California Sur.

SEDESOL. 2002b. Estadísticas Históricas 1956-1975. Territorio Sur de Baja California. La Paz, Mexico: Gobierno del Estado de Baja California Sur.

SEDESOL. 2003. Estadísticas Históricas 1975-1998. Estado de Baja California Sur. La Paz, Mexico: Gobierno del Estado de Baja California Sur.

Solecki, W. D., and C. Oliveri. 2004. Downscaling climate change scenarios in an urban land use change model. Journal of Environmental Management 72:105-115. http://dx.doi.org/10.1016/ j.jenvman.2004.03.014

Stasiak, A. 1992. Problems of depopulation of rural areas in Poland after 1950. Landscape and Urban Planning 22:161-175. http://dx.doi.org/10.1016/0169-2046(92)90020-Z

Sterman, J. D. 2000. Business dynamics: systems thinking and modeling for a complex world. Irwin/McGraw-Hill, Boston, Massachusetts, USA.

Stockdale, A. 2004. Rural out-migration: community consequences and individual migrant experiences. Sociologia Ruralis 44:167-194. http://dx.doi.org/10.1111/j.1467-9523.2004.00269. $\underline{x}$

Tenza, A., I. Pérez-Ibarra, J. Martínez-Fernández, F. J. Conway, M. Cariño, L. Castorena, A. Breceda, and A. Giménez. 2013. Estructura y funcionamiento dinámico del oasis. Pages 33-57 in M. Cariño, A. Breceda, A. Ortega, and L. Castorena, editors. Evocando el edén. Conocimiento, valoración y problemática del Oasis de Los Comondú. Icaria editorial S. A., Barcelona, Spain. 
Tomlinson, B., S. Sastre, D. Blasco, and J. Guillén. 2011. The systems approach framework as a complementary methodology of adaptive management: a case study in the urban beaches of Barcelona. Ecology and Society 16(4):28. http://dx.doi. org/10.5751/es-04484-160428

Turchin, P., and S. A. Nefedov. 2009. Secular cycles. Princeton University Press, Princeton, New Jersey, USA. http://dx.doi. org/10.1515/9781400830688

Turner, B. L., V. Tidwell, A. Fernald, J. A. Rivera, S. Rodriguez, S. Guldan, C. Ochoa, B. Hurd, K. Boykin, and A. Cibils. 2016. Modeling Acequia irrigation systems using system dynamics: model development, evaluation, and sensitivity analyses to investigate effects of socio-economic and biophysical feedbacks. Sustainability 8(10):1019. http://dx.doi.org/10.3390/su8101019

Urciaga, J. 2008. La agricultura en Baja California Sur. Una perspectiva de largo plazo (1900-2005). Pages 249-278 in M. Cariño and M. Monteforte, editors. Del saqueo a la conservación. Historia ambiental contemporánea de Baja California Sur, 19402003. UABCS, SEMARNAT, INE, and CONACYT, Mexico City, Mexico.

Urgenson, L. S., R. K. Hagmann, A. C. Henck, S. Harrell, T. M. Hinckley, S. J. Shepler, B. L. Grub, and P. M. Chi. 2010. Socialecological resilience of a Nuosu community-linked watershed, southwest Sichuan, China. Ecology and Society 15(4):2. http://dx. doi.org/10.5751/es-03568-150402

Vang Rasmussen, L., and A. Reenberg. 2012. Collapse and recovery in Sahelian agro-pastoral systems: rethinking trajectories of change. Ecology and Society 17(1):14. http://dx. doi.org/10.5751/es-04614-170114

Vennix, J. A. M. 1996. Group model building. facilitating team learning using system dynamics. John Wiley \& Sons, Chichester, UK.

Vidal-Legaz, B., J. Martínez-Fernández, A. Sánchez-Picón, and F. I. Pugnaire. 2013. Trade-offs between maintenance of ecosystem services and socio-economic development in rural mountainous communities in southern Spain: a dynamic simulation approach. Journal of Environmental Management 131:280-297. http://dx.doi.org/10.1016/j.jenvman.2013.09.036

Walker, B., L. Gunderson, A. Kinzig, C. Folke, S. Carpenter, and L. Schultz. 2006. A handful of heuristics and some propositions for understanding resilience in social-ecological systems. Ecology and Society 11(1):13. http://dx.doi.org/10.5751/es-01530-110113

Wolstenholme, E. 1990. System enquiry: a system dynamics approach. John Wiley \& Sons, New York, USA.

Wurl, J., J. C. Graciano, and A. E. Gámez. 2013. Disponibilidad, calidad y manejo del agua para su uso productivo y humano en Los Comondú. Pages 149-177 in A. E. Gámez, editor. Opciones de desarrollo en el oasis de Los Comondú. La Paz, Mexico: Gobierno del Estado de Baja California Sur, Instituto Sudcaliforniano de Cultura, Universidad Autónoma de Baja California Sur, Consejo Nacional de Ciencia y Tecnología.

Xiao-Qing, Z., R. Hui, Y. Qi, H. Chun-lan, and Y. Hong-hui. 2012. Scenarios simulation on carrying capacity of water resources in Kunming City. Procedia Earth and Planetary Science 5:107-112. http://dx.doi.org/10.1016/j.proeps.2012.01.018

Young, O. R., F. Berkhout, G. C. Gallopin, M. A. Janssen, E. Ostrom, and S. van der Leeuw. 2006. The globalization of socioecological systems: an agenda for scientific research. Global Environmental Change 16:304-316. http://dx.doi.org/10.1016/j. gloenvcha.2006.03.004 
Appendix 1. List of RIDISOS researcher members.

\begin{tabular}{|c|c|c|}
\hline Name & Discipline & Academic institution \\
\hline Alba. E Gámez & Economy & $\begin{array}{l}\text { Universidad Autónoma de Baja } \\
\text { California Sur, Mexico }\end{array}$ \\
\hline $\begin{array}{l}\text { Alexandra } \\
\text { Sauvage }\end{array}$ & Cultural history & $\begin{array}{l}\text { Universidad Autónoma de Baja } \\
\text { California Sur, Mexico }\end{array}$ \\
\hline Alicia Tenza & $\begin{array}{l}\text { Environmental sciences and } \\
\text { Agroecology }\end{array}$ & $\begin{array}{l}\text { Universidad Miguel Hernández, } \\
\text { Spain }\end{array}$ \\
\hline Andrés Giménez & Ecology & $\begin{array}{l}\text { Universidad Miguel Hernández, } \\
\text { Spain }\end{array}$ \\
\hline Antonina Ivanova & Economy & $\begin{array}{l}\text { Universidad Autónoma de Baja } \\
\text { California Sur, Mexico }\end{array}$ \\
\hline Antonio Ortega & Environmental history & Universidad de Granada, Spain \\
\hline Aurora Breceda & Ecology & $\begin{array}{l}\text { Centro de Investigaciones Biológicas } \\
\text { del Noroeste (CIBNOR), Mexico }\end{array}$ \\
\hline Eduardo Juárez & Economy & $\begin{array}{l}\text { Universidad Autónoma de Baja } \\
\text { California Sur, Mexico }\end{array}$ \\
\hline $\begin{array}{l}\text { Frederick J. } \\
\text { Conway }\end{array}$ & Anthropology & $\begin{array}{l}\text { University of San Diego, United } \\
\text { States of America }\end{array}$ \\
\hline Irene Pérez & Ecology and Sociology & $\begin{array}{l}\text { Arizona State University, United } \\
\text { States of America }\end{array}$ \\
\hline Jobst Wurl & Hydrogeology & $\begin{array}{l}\text { Universidad Autónoma de Baja } \\
\text { California Sur, Mexico }\end{array}$ \\
\hline $\begin{array}{l}\text { José A. Martínez } \\
\text { de la Torre }\end{array}$ & Economy & $\begin{array}{l}\text { Universidad Autónoma de Baja } \\
\text { California Sur, Mexico }\end{array}$ \\
\hline Julia Martínez & Ecology & $\begin{array}{l}\text { Fundación Nueva Cultura del Agua, } \\
\text { Spain }\end{array}$ \\
\hline Lorella Castorena & Sociology & $\begin{array}{l}\text { Universidad Autónoma de Baja } \\
\text { California Sur, Mexico }\end{array}$ \\
\hline Mario Monteforte & Marine Biology & $\begin{array}{l}\text { Centro de Investigaciones Biológicas } \\
\text { del Noroeste (CIBNOR), Mexico }\end{array}$ \\
\hline Micheline Cariño & Environmental history & $\begin{array}{l}\text { Universidad Autónoma de Baja } \\
\text { California Sur, Mexico }\end{array}$ \\
\hline Paul Nabhan & Ecology and Ethnobotany & $\begin{array}{l}\text { Universty of Arizona, United States } \\
\text { of America }\end{array}$ \\
\hline $\begin{array}{l}\text { Rafael de } \\
\text { Granade }\end{array}$ & $\begin{array}{l}\text { Cultural anthropology and } \\
\text { Agricultural Plant Science }\end{array}$ & $\begin{array}{l}\text { University of Arizona, United States } \\
\text { of America }\end{array}$ \\
\hline Yolanda Maya & Edaphology & $\begin{array}{l}\text { Centro de Investigaciones Biológicas } \\
\text { del Noroeste (CIBNOR), Mexico }\end{array}$ \\
\hline
\end{tabular}


Appendix 2. Interview scripts.

\section{General Interview: irrigation, land tenure and community (population and services)}

(conducted between November-December 2010)

\section{Block 1. Characterization of the interviewee}

What is your name?

How old are you?

Were you born in this community?

Have you always lived here? If not ... Where? For how long? Why did you come back?

Were your parents from here?

In what productive activity are you engaged?

\section{Block 2. Characterization of the orchard}

Do you have an orchard in this community? Are you the owner of the orchard or are you in charge?

How large is your orchard?

Is your orchard currently in production? What do you produce? How much do you produce in a year (or a season)? How long have you been working on this orchard?

How long have you been engaged in agricultural activity?

What activities do orchard maintenance and production include?

Has the orchard always been in production or has it been inactive during a prior period? If it has been inactive, when? For how many years?

What did you grow before? If you changed, why did you change the crop type?

Block 3. Characterization of the agricultural activity in the community

Do you remember seeing all the orchards in production? When?

Could you tell me about the maximum area that has been in production?

What is the average area of the orchards? What is the maximum and minimum area?

What are the main crops of the community? Have they changed with time? Why?

How much could be produced on a plot of dates, figs, grapes or sugar cane in a year?

Some of the orchards that we visited have been abandoned for 30 and 40 years. Do you

know of any cases where someone has recovered an abandoned orchard? Why?

When were orchards larger? How many? Who were the owners? What happened to the people who did not own orchards?

What is the traditional land inheritance system in the oasis? 


\section{Block 4. Marketing and profitability of agricultural activity}

Has there been any association or cooperative that has marketed agricultural production? How was the product marketed in the past? And now?

Where were orchard products sold? And now?

Does the community use inputs (pesticides, fertilizers, etc.) for the orchards?

Was livestock farming performed at the same time as the orchards?

Is the agricultural activity complemented by livestock? Has it sold manure as a fertilizer to neighbors?

Why do you think the agricultural activity stopped being profitable?

To what extent do you think that the opening of the Santo Domingo Valley has affected production of the oasis?

When did the population engage more time in livestock activity than in agriculture? Is it more profitable?

When were goats introduced into Comondú? Did it form part of some government support?

What are the main reasons for abandoning orchards?

\section{Block 5. Irrigation}

What kind of irrigation was used on the orchards in the past?

Did any local institution regulate the irrigation of orchards? How did it work?

What was irrigation system cleaning and maintenance like? And now?

When did the institution for irrigation stop working?

What was the reason for the disruption?

What is irrigation like now?

\section{Block 6. Land tenure}

Are you an ejidatario or a private owner?

What properties do you have (housing, orchard, ranch)? What is the property type for each one?

When was the Ejido created?

Did all families have the opportunity to form part of the Ejido?

Did the creation of the Ejido affect orchards being abandoned?

\section{Block 7. Characterization of the community}

Has the number of neighbors varied with time? Could you estimate the maximum number of neighbors who have lived here in relation to a specific date?

What services did the community have before (schools, shops, post office, telegraphs, etc.)? What year did each one cease being active?

From your point of view, which of the services you mentioned was the most important? And the least? 
Were there festivities or dances in the community? How often? When did they stop being held?

Do you remember any period during which a larger number of residents migrated to other parts? When?

What were the main reasons for this migration?

\section{General interview: ranches}

(Conducted in January 2011)

Block 1. Characterization of the interviewee

Name:

Age:

Name of community:

How many years have you worked with livestock?

\section{Block 2. Characterization of the ranch}

What is the name of your ranch?

Are you the owner of the ranch or you are a worker?

What type of property is the ranch?

Have you always lived in the area? How long have you worked at or have you owned the ranch?

What surface area does your ranch cover?

How much area is used for cattle? And for goats?

\section{Block 3. Characterization of livestock activity}

How many heads of cattle do you currently have? and goats?

What is the largest number of cattle and goats that you have had? When was this?

And the fewest? When was this?

How long have you had goats?

What factors determine changes in livestock with time?

What are the reasons for you not having more cattle (ranch size, economic reasons)?

Where do your livestock graze on?

Do you change grazing areas throughout the year or between years? Why? How? Are there mechanisms for rangeland management? Are there rules for rangeland regeneration?

\section{Block 4. Production and profitability of livestock activity}

How many people work on the ranch? Are they a family?

What production figures does your ranch yield? How has it changed with time? 
How do you market the production of your ranch? How has it changed with time?

What are the production costs of your ranch? How have they changed over time?

Are there any differences between costs of goats and cattle?

What is the profitability of livestock? How has it changed with time?

Are there any differences between the profitability of cattle and goats? If so, what are they?

What is the self-consumption production?

How many people depend on the resources obtained from your ranch?

\section{Block 5. Effects of weather}

Do you remember years with heavy rain? When? How does rain affect the ranch (grass, livestock, production)?

And drought periods? When? How does drought affect the ranch (grass, livestock, production)?

Have you experienced events like hurricanes? Do you remember any specific hurricane?

When did it occur? How did it affect the ranch? How much livestock loss occurred in these events?

What do you do to adapt to extreme weather events?

Block 6. Relations with the community and other ranches

How do you relate to the community? How often do you visit the community? What are the main reasons for going to the community?

How are rangeland areas shared among neighboring ranches?

Is there any conflict?

Block 7. Perceived problems in livestock activity and future perspectives

What problems does livestock activity entail now?

Have any ranches been abandoned? Since when? How much? Where?

Do generational replacements take place to work in livestock activity?

How do you see the future of ranching? Do you want to continue with it? What about your children?

What could improve the current situation of ranches?

\section{Specific interview: migrants}

(Conducted in February 2012)

What is your name?

How old are you?

Where were you born?

How many years have you lived in the oasis of Comondú?

How old were you when you left the oasis of Comondú? 
How would you describe the life in the oasis when you lived there (neighbors, economic activities, services, festivities, etc.)?

What reasons helped you make the decision to migrate from the Oasis Comondú (educational opportunities, work, health, quality of life, etc.)?

Did some friend, neighbor or family member (who had migrated before) help you to make the decision?

Did you need financial support to migrate from the oasis? Did this support come from your family? What main economic activities did your family undertake in the oasis of Comondú?

\section{Specific interview: livestock activity}

(Conducted in August 2012)

How many goats or cattle are necessary to start a herd?

How many years do goats live? And cattle? How many years can goats breed? And cattle? What are livestock activity costs? (Labor, fuel, etc.)

How many people are needed to manage a ranch? How many cattle or goats can one single person handle?

What costs increase with drought?

What happens to prices? Can you offset costs? How many differences are there between the profits and costs of livestock during drought periods?

Imagine a herd of 100 goats or cattle, and a dry year begins ... What would happen to that herd? How many goats or cattle would die? Would you sell all goatlings or calves (females and males) in that year? What would happen if the drought lasted another year? and 2 years?

Does a dry year have any effects on rangelands?

What factors (profitability, duration of droughts, herd size) could affect making a decision about abandoning livestock activity? Which of these factors has more weight?

What is done with the animals when a rancher decides to leave a ranch? 
Appendix 3. Summary of quantitative data from fieldwork.

\begin{tabular}{|c|c|c|}
\hline Parameter & Value & Units \\
\hline $\begin{array}{l}\text { Abandonment rate of irrigated land (reference } \\
\text { value) }\end{array}$ & 0.0025 & 1/year \\
\hline $\begin{array}{l}\text { Animal units per cattle (used to calculate the } \\
\text { carrying capacity of rangeland) }\end{array}$ & 1 & AU/cattle \\
\hline $\begin{array}{l}\text { Animal units per goat (used to calculate the } \\
\text { carrying capacity of rangeland) }\end{array}$ & 0.17 & AU/goat \\
\hline Average rainfall (1940-2010) & 175 & $\mathrm{~mm} /$ Year \\
\hline Birth rate of cattle & 0.57 & 1/year \\
\hline Birth rate of goats & 1 & 1/year \\
\hline $\begin{array}{l}\text { Carrying capacity of rangeland (reference } \\
\text { value) }\end{array}$ & 29.6 & $\mathrm{Ha} / \mathrm{AU}$ \\
\hline Cattle per labor unit & 100 & Cattle/person \\
\hline Cheese production per goat (reference value) & 21 & $\mathrm{Kg} /$ year \\
\hline Common lands area ("Ejido") & 69,873 & ha \\
\hline Economically active population & 0.34 & Dimensionless \\
\hline Emigration rate of population (reference value) & 0.02 & 1/year \\
\hline Labor per unit area in irrigated land & 1 & Persons/ha \\
\hline $\begin{array}{l}\text { Number of "ejidatarios" (users of common } \\
\text { lands) }\end{array}$ & 60 & Persons \\
\hline Number of goats per labour unit & 133 & Goats/person \\
\hline Population birth rate & 0.031 & $1 /$ year \\
\hline Population death rate & 0.0095 & 1/year \\
\hline Private property area & 36,800 & ha \\
\hline Production per hectare for reference crops & 2,663 & $\mathrm{Kg} / \mathrm{ha}$ \\
\hline Sale rate of adult goats (reference value) & 0.05 & 1/year \\
\hline Sale rate of cattle & 0.19 & 1/year \\
\hline Sale rate of young goats (reference value) & 0.5 & 1/year \\
\hline Total predation of cattle (in drought periods) & 400 & Cattle/year \\
\hline Total predation of goats (in drought periods) & 1,000 & Goats/year \\
\hline Weight of cattle for sale & 250 & $\mathrm{Kg} /$ cattle \\
\hline Weight of goat for sale & 12 & $\mathrm{Kg} /$ goat \\
\hline
\end{tabular}

